\title{
Simulating cold-region hydrology in an intensively drained agricultural watershed in Manitoba, Canada, using the Cold Regions Hydrological Model
}

\author{
Marcos R. C. Cordeiro ${ }^{1}$, Henry F. Wilson ${ }^{2}$, Jason Vanrobaeys ${ }^{3}$, John W. Pomeroy ${ }^{4}$, Xing Fang ${ }^{4}$, and The \\ Red-Assiniboine Project Biophysical Modelling Team* \\ ${ }^{1}$ Science and Technology Branch, Agriculture and Agri-Food Canada, Winnipeg, R3C 3G7, Canada \\ ${ }^{2}$ Science and Technology Branch, Agriculture and Agri-Food Canada, Brandon, R7A 5Y3, Canada \\ ${ }^{3}$ Science and Technology Branch, Agriculture and Agri-Food Canada, Morden, R6M 1Y5, Canada \\ ${ }^{4}$ Centre for Hydrology, University of Saskatchewan, Saskatoon, S7N 5C8, Canada \\ *A full list of authors and their affiliations appears at the end of the paper.
}

Correspondence to: Henry F. Wilson (henry.wilson@agr.gc.ca)

Received: 2 September 2016 - Discussion started: 27 September 2016

Revised: 23 May 2017 - Accepted: 31 May 2017 - Published: 12 July 2017

\begin{abstract}
Etrophication and flooding are perennial problems in agricultural watersheds of the northern Great Plains. A high proportion of annual runoff and nutrient transport occurs with snowmelt in this region. Extensive surface drainage modification, frozen soils, and frequent backwater or icedamming impacts on flow measurement represent unique challenges to accurately modelling watershed-scale hydrological processes. A physically based, non-calibrated model created using the Cold Regions Hydrological Modelling platform (CRHM) was parameterized to simulate hydrological processes within a low slope, clay soil, and intensively surface drained agricultural watershed. These characteristics are common to most tributaries of the Red River of the north. Analysis of the observed water level records for the study watershed (La Salle River) indicates that ice cover and backwater issues at time of peak flow may impact the accuracy of both modelled and measured streamflows, highlighting the value of evaluating a non-calibrated model in this environment. Simulations best matched the streamflow record in years when peak and annual discharges were equal to or above the medians of $6.7 \mathrm{~m}^{3} \mathrm{~s}^{-1}$ and $1.25 \times 10^{7} \mathrm{~m}^{3}$, respectively, with an average Nash-Sutcliffe efficiency (NSE) of 0.76. Simulation of low-flow years (below the medians) was more challenging (average NSE $<0$ ), with simulated discharge overestimated by $90 \%$ on average. This result indicates the need for improved understanding of hydrological
\end{abstract}

response in the watershed under drier conditions. Simulation during dry years was improved when infiltration was allowed prior to soil thaw, indicating the potential importance of preferential flow. Representation of in-channel dynamics and travel time under the flooded or ice-jam conditions should also receive attention in further model development efforts. Despite the complexities of the study watershed, simulations of flow for average to high-flow years and other components of the water balance were robust (snow water equivalency (SWE) and soil moisture). A sensitivity analysis of the flow routing model suggests a need for improved understanding of watershed functions under both dry and flooded conditions due to dynamic routing conditions, but overall CRHM is appropriate for simulation of hydrological processes in agricultural watersheds of the Red River. Falsifications of snow sublimation, snow transport, and infiltration to frozen soil processes in the validated base model indicate that these processes were very influential in stream discharge generation.

Copyright statement. The works published in this journal are distributed under the Creative Commons Attribution 3.0 License. This license does not affect the Crown copyright work, which is re-usable under the Open Government Licence (OGL). The Creative Commons Attribution 3.0 License and the OGL are 
interoperable and do not conflict with, reduce or limit each other.

C Crown copyright 2017

\section{Introduction}

The Red River Basin spans over $122730 \mathrm{~km}^{2}$ and encompasses portions of Canada (provinces of Manitoba and Saskatchewan) and the United States (North Dakota, South Dakota, and Minnesota), with almost three-quarters of its land used for agriculture (Benoy et al., 2016). As a result, most of the hydrology and nutrient transport in that basin are strongly influenced by this land use. The interaction between agricultural management and the hydrology of cold regions remains a topic of ongoing research (Rahman et al., 2014; King et al., 2015) given the need for improved understanding of processes such as prevalence of preferential flowpaths, enhanced hydrological connectivity promoted by drainage, and impact of different cropping systems on runoff generation. Hydrological models have been utilized at varying spatial scales to model the hydrology of agricultural areas of cold-climate countries such as Finland (Grizzetti et al., 2003; Knisel and Turtola, 2000), Russia (Schierhorn et al., 2014a, b), and Canada (Yang et al., 2014, 2009). Overall, little research addressing specificities of agriculture in cold-region hydrology is available in the literature, although this activity is quite relevant in northern latitude regions such as the northern Great Plains (North America; Desaulniers and Gritzner, 2006; Wishart, 2004; Sharp, 1952; Li et al., 2010), northwestern Europe (Scandinavia; Parry et al., 1988), and northern Asia (Wang et al., 2002; Blanke et al., 2007). Important challenges remain in modelling the hydrology of northern latitude agricultural watersheds, such as integrated modelling of cropping systems and hydrology, representation of processes across spatial scales, and enhanced hydrologic connectivity. For example, crops represented only $30 \%$ of the land use in a study in Finland using the Soil and Water Assessment Tool (SWAT), making direct connection to agricultural processes more challenging (Grizzetti et al., 2003), while an application of the GLEMS model in that country was done at plot scale ( 0.11 ha in area), providing detail but making scaling up a challenge (Knisel and Turtola, 2000). SWAT simulations in Russia have focussed on productivity aspects of wheat only rather than hydrological implications (Schierhorn et al., 2014a ,b) and SWAT exercises in Canada have focussed on finer-scale simulation of a specific management practices rather than evaluating process representation (i.e. $14.5 \mathrm{~km}^{2}$ watershed area; Yang et al., 2009), or were assessed on too coarse (i.e. monthly) a time step for physically based modelling of snowmelt (Yang et al., 2014).

Many popular models utilized for the simulation of hydrological processes in agricultural watersheds were initially developed for regions where rainfall driven runoff is the primary contributor to annual water yield. Snowmelt is the main source of streamflow in tributaries of the Red River and accurate representation of hydrological processes in its agricultural tributaries using popular models like SWAT has proved challenging. While SWAT has been used to estimate water quality targets and beneficial management practices in Canada (Yang et al., 2012), significant modification of the original model is generally required to achieve a good fit with calibration data (Watson et al., 2008; Liu et al., 2012) and improvement of the accuracy of underlying representation of important hydrological processes (e.g. landscape representation, stream routing) is ongoing (Douglas-Mankin et al., 2010).

As a result of the problems associated with adapting hydrological models developed for more temperate conditions, a number of models that incorporate cold-region hydrological processes have been developed, such as ARHYTHM (Zhang et al., 2000), VIC (Cherkauer et al., 2003), the THREW model (Mou et al., 2008; Tian et al., 2006), and the Cold Regions Hydrological Modelling (CRHM) platform (Pomeroy et al., 2007). Of these models, CRHM offers the most complete range of physically based process representation for the northern Great Plains, including blowing snow, interception and sublimation of snow, energy balance snowmelt, canopy influence on radiation, and infiltration to frozen soils (Pomeroy et al., 2007; Fang et al., 2010, 2013). Although CRHM currently does not feature a module to represent nutrient dynamics in either soil or water, such modules are under development (Roste, 2015) and the platform is a powerful tool for assessing watershed nutrient dynamics because of the well-established relationships between phosphorus concentrations and discharge rate in tributaries of the Red River, including the La Salle River (McCullough et al., 2012), which is the focus of the research presented here.

The CRHM platform has been successfully used to simulate hydrological processes in a number of contrasting catchments in Canada (Dornes et al., 2008; Fang and Pomeroy, 2008; Ellis et al., 2010) and globally, in western China (Zhou et al., 2014), Patagonia (Krogh et al., 2015), the German Alps (Weber et al., 2016), and the Spanish Pyrenees (Rasouli et al., 2014), and in the intensively studied South Tobacco Creek watershed that drains from the more steeply sloped Pembina/Manitoba Escarpment feature into the Red River in Manitoba (Mahmood et al., 2017). However, the CRHM has not yet been used to simulate hydrological processes in the intensively managed lowland agricultural tributaries of the Red River such as the La Salle River. Characteristics in these watersheds include extensive artificial surface drainage, channelization of the stream network, historical drainage of wetlands, clay soils, high fertilizer input, high crop yields, high livestock densities, and highly connected drainage areas with little surface storage. Simulation of cold-region hydrological processes in this landscape is particularly challenging because of the combined effect of climate and land use management on water transport. Large volumes of runoff can be produced when snowmelt is routed 


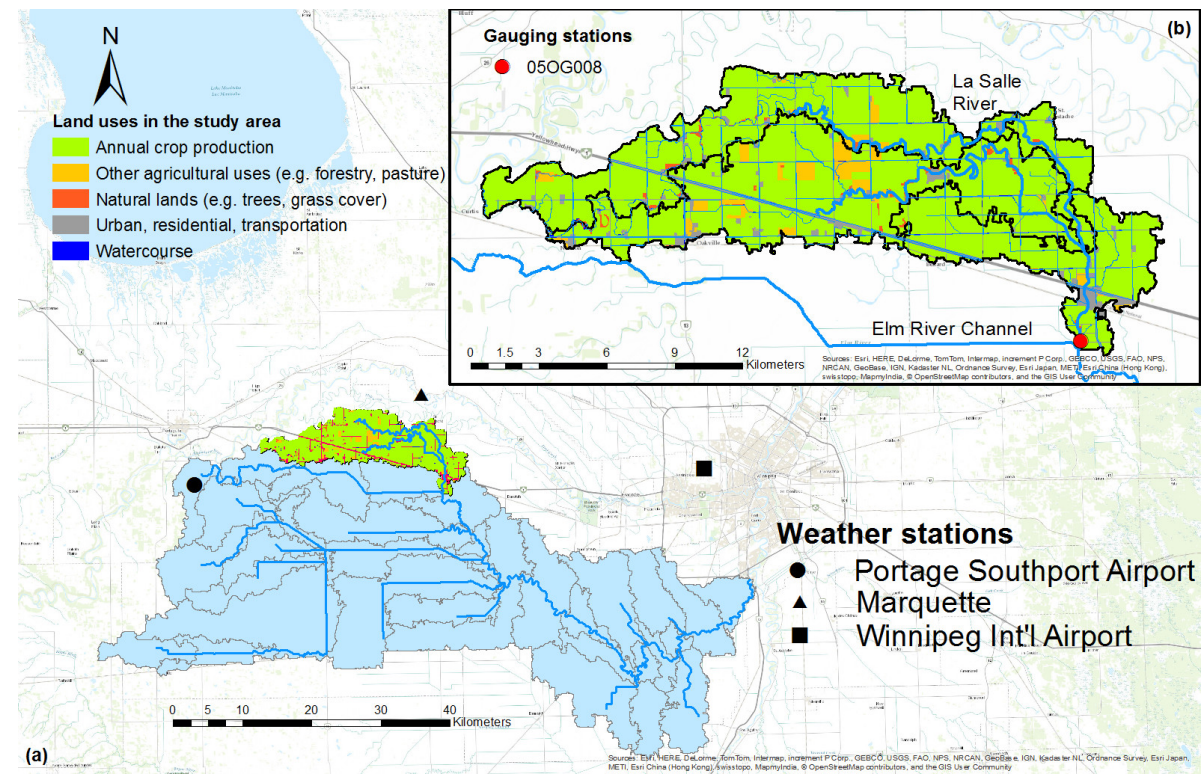

Figure 1. The La Salle watershed (a) and the sub-watershed used in the study, which drains into Water Survey Canada gauging station $050 G 008$ (b).

over frozen soils (Shook and Pomeroy, 2010, 2012) and this process is emphasized where surface drainage enhancements and roadside ditches speed up transport (Brunet and Westbrook, 2012; Pomeroy et al., 2014). As a result, flows in streams of the Red River watershed tend to exhibit a flashy response to snowmelt, with large volumes of runoff from roadside ditches entering into relatively small river channels that are still covered by ice at the time of melting. This inchannel ice restricts flow and frequently causes flooding and backwater conditions to develop (Gray and Prowse, 1993). These conditions can lead to error in discharge measurements calculated using stage-rating curves (Mosley and McKerchar, 1993) and also invalidate important assumptions of flow routing models (Fread, 1993), thus making accurate prediction of flow more challenging. For this reason, using a noncalibrated but flexible physically based model platform is an attractive alternative to models primarily calibrated based on discharge measurements. The application of the CRHM will enhance the understanding of the hydrological controls in tributaries of the Red River since concurrent measurements such as SWE and soil moisture can also be utilized to gauge the accuracy of model process representations independent of uncertainties associated with in-stream flow representation or measurement. At the same time, the limitations of existing conceptual models and/or potential problems with discharge measurement should be more apparent in the absence of calibration (Spence et al., 2013).

While the CRHM has performed well in a number of watersheds across Canada, its performance has not been evaluated in intensively managed agricultural watersheds in the Canadian Prairies, which is home to $80 \%$ of the coun- try's agriculture (Wheater and Gober, 2015). Prairie agroecosystems are characterized by modified topography, annual cropping systems, and enhanced hydrologic connectivity that set them apart from other cold-region ecosystems, and it has been challenging to accurately model these processes using other platforms. The objective of this study was to perform hydrological simulations in a framework specifically designed to represent agricultural systems typical of the Red River Basin, to identify challenges hindering satisfactory simulation of these systems, and to utilize the processbased CRHM to identify where conceptual hydrological models for cold agricultural regions might be improved. Specifically, the CRHM was used to simulate the hydrology of an intensively managed agricultural sub-watershed of the Red River Valley and to gain insight into the dominant hydrological controls of streamflow in this landscape that, although unique, embodies many of the problems faced by other cold regions. For example, phosphorus transport from farmland, which is a problem in the Red River Basin (Rattan et al., 2016; Yates et al., 2012), is also an issue in many other coldclimate regions, including northwestern European countries such as Norway, Sweden, the United Kingdom, and Ireland (Ulén et al., 2007). The research presented here provides insight into those periods of time, weather conditions, and associated process representations with which poor model performance is associated, indicating either limitations of model input data or the need for improved understanding and representation of watershed hydrology in the region. 


\section{Material and methods}

\subsection{Study site}

The study was conducted in a $189 \mathrm{~km}^{2}$ sub-catchment of the La Salle River watershed (LS-05OG008; Fig. 1a), a tributary of the larger Red River which is located in the central plains region of Manitoba, Canada (Graveline and Larter, 2006). Only the sub-catchment was used in the present study due to weather data availability in an hourly time step, which was required to force some physically based processes in CRHM, such as the Prairie Blowing Snow Model (Pomeroy and Li, 2000). The study watershed is underlain by lacustrine clay deposited in glacial Lake Agassiz; these deposits consist of a lower, dark grey clay and a thinner upper unit of lighter coloured, calcareous silty clay, with surface texture being predominantly clayey (La Salle Redboine Conservation District, 2007). The study area is located in the Prairie Ecozone, with mean annual temperature around $2.5^{\circ} \mathrm{C}$, a mean summer temperature of $16^{\circ} \mathrm{C}$ and a mean winter temperature of $-13^{\circ} \mathrm{C}$; the mean annual precipitation is $560 \mathrm{~mm}$, of which around $25 \%$ takes place as snow, while the potential mean annual gross evapotranspiration is about $834 \mathrm{~mm}(\mathrm{La}$ Salle Redboine Conservation District, 2007).

\subsection{Hydrological and meteorological observations}

Daily streamflow observations between 1990 and 2013 were obtained from the hydrometric data (HYDAT) database (Environment and Climate Change Canada, 2015b) for Water Survey of Canada (WSC) gauging station 05OG008 (La Salle River near Elie; Fig. 1b) located at the outlet of the study watershed. Data collection at this location was seasonal from 1990 to 1996, and has been continuous from 2002 to the present. The annual monitoring period for this station spans from 1 March to 31 October, with no data available during winter months; thus, analyses were carried out using calendar years rather than water years (i.e. 1 October to 30 September) since the hydrometric data do not span over more than a calendar year. A gap in available flow data exists between flooding in 1997 and instrument replacement in 2001. Only flow data are available from HYDAT for the period prior to 1996, while flow and water level were both recorded from 2002 onwards. Notes in the HYDAT metadata pertaining to 2004 and 2008 indicated equipment malfunctions resulting in loss of data. For this reason, the periods from 1997-2001, 2004, and 2008 were not used for model assessment.

Gauging station $050 \mathrm{OG} 008$ is located $80 \mathrm{~m}$ downstream from a small water level control structure, which raises concerns about ice jamming and backwater issues. The operation of the control structure is not changed throughout the year (i.e. no stop-logs removed) since the purpose of the structure is to increase the storage of the river channel during the summer months (when discharge is low). Therefore, stream discharge is not significantly affected by human operations of the control structure. Ice conditions are flagged in the HYDAT daily records, but no further detail is provided. It was assumed that ice conditions meant complete or major ice cover at initial ice breakup. While ice conditions are flagged in HYDAT, backwater and flooding conditions are not indicated for the site. Thus, field notes from site visits were acquired from WSC and used to determine potential backwater conditions. The threshold for flagging these conditions in the present analysis was based on the minimum water level for which backwater was recorded by WSC technicians in the field. This level was $239.3 \mathrm{~m}$, observed on 19 May 2011, which is only $0.2 \mathrm{~m}$ below the full supply level (FSL) of the water level control structure $(239.5 \mathrm{~m})$. Potential backwater conditions were assumed whenever the water level was above this threshold. Since water levels in the HYDAT database were only available after 2002 , this analysis was carried out between 2002 and 2013. These potential backwater periods are noted in figures displaying measured discharge. However, the presence of backwater conditions, although common, was not consistently documented in the WSC field notes to provide verification of occurrence or impact on measurement accuracy, so even where backwater conditions were suspected, all flow data were assumed accurate and utilized in assessment of model performance.

The hourly weather data used to force CRHM were obtained from the closest Environment Canada weather station (Environment and Climate Change Canada, 2015a) with available data (Fig. 1a). Nearby stations are located at Portage Southport Airport, Winnipeg International Airport, and Marquette (26.6, 47.9, and $9.9 \mathrm{~km}$ from the geometric centre of the study area, respectively). Air temperature, wind speed, and relative humidity were obtained from Portage Southport Airport, solar radiation was acquired from the station located at Winnipeg International Airport, and precipitation was acquired from the weather station in Marquette. Precipitation was available in a daily time step and was disaggregated to an hourly time step using HyetosR (Kossieris et al., 2013), which is a package for the temporal stochastic simulation of rainfall process at fine timescales based on the Bartlett-Lewis rectangular pulses rainfall model (Koutsoyiannis and Onof, 2001). Details about the hydrological and meteorological datasets are provided by Cordeiro et al. (2017, https://doi.org/10.5194/essd-2017-57).

\subsection{Watershed delineation and HRU definition}

The soils, topography, and land use datasets used as model inputs in this study were derived according to the principles described by Liu et al. (2013) for prediction in ungauged basins. The sub-basins within the La Salle watershed (Fig. 1a) were defined in a previous modelling exercise using the watershed delineation tool in SWAT (Yang et al., 2014) and the $90 \mathrm{~m}$ digital elevation model (DEM) derived from the NASA Shuttle Radar Topography Mission data. Soil datasets with scales ranging from 1:20000 to 
Table 1. List of hydrologic response units (HRUs) used in the LS-05OG008 watershed.

\begin{tabular}{|c|c|c|c|c|c|c|c|c|}
\hline \multirow[t]{2}{*}{ HRU ID } & \multirow[t]{2}{*}{ HRU acronym* } & \multirow[t]{2}{*}{ Cropping system/land use } & \multirow[t]{2}{*}{ Crop } & \multirow[t]{2}{*}{ Soil texture } & \multicolumn{4}{|c|}{ Occurrence } \\
\hline & & & & & SB 2 & SB 3 & SB 5 & SB 33 \\
\hline 1 & IVPO/SICL & Irrigated vegetable & Potato & Silty clay loam & Yes & Yes & No & Yes \\
\hline 2 & IVPO/C & Irrigated vegetable & Potato & Clay & No & Yes & No & No \\
\hline 3 & IVCR/SICL & Irrigated vegetable & Carrot & Silty clay loam & Yes & Yes & No & Yes \\
\hline 4 & IVCR/C & Irrigated vegetable & Carrot & Clay & No & Yes & No & No \\
\hline 5 & PRSB/SIC & Pulse non-row & Soybean & Silty clay & No & Yes & No & No \\
\hline 6 & $\mathrm{PRSB} / \mathrm{C}$ & Pulse non-row & Soybean & Clay & No & Yes & No & No \\
\hline 7 & PFAF/C & Perennial forage & Alfalfa & Clay & Yes & Yes & No & Yes \\
\hline 8 & PRSW/SIC & Pulse non-row & Spring wheat & Silty clay & No & Yes & No & No \\
\hline 9 & PRSW/C & Pulse non-row & Spring wheat & Clay & No & Yes & No & No \\
\hline 10 & $\mathrm{PFSW} / \mathrm{C}$ & Perennial forage & Spring wheat & Clay & Yes & Yes & No & Yes \\
\hline 11 & OSSW/C & Oilseed - spring cereal & Spring wheat & Clay & Yes & Yes & Yes & Yes \\
\hline 12 & $\mathrm{FCSW} / \mathrm{C}$ & Fall cereal & Spring wheat & Clay & Yes & Yes & Yes & No \\
\hline 13 & FCWW/C & Fall cereal & Winter wheat & Clay & Yes & Yes & Yes & No \\
\hline 14 & PRCA/SIC & Pulse non-row & Canola & Silty clay & No & Yes & No & No \\
\hline 15 & PRCA/C & Pulse non-row & Canola & Clay & No & Yes & No & No \\
\hline 16 & OSCA/C & Oilseed - spring cereal & Canola & Clay & Yes & Yes & Yes & Yes \\
\hline 17 & FCCA/C & Fall cereal & Canola & Clay & Yes & Yes & Yes & No \\
\hline 18 & FYDL/SICL & Feedlot & - & Silty clay loam & No & No & No & Yes \\
\hline 19 & FYDL/C & Feedlot & - & Clay & Yes & No & No & No \\
\hline 20 & URLD/SICL & Urban (low density) & - & Silty clay loam & Yes & Yes & No & Yes \\
\hline 21 & URLD/C & Urban (low density) & - & Clay & Yes & Yes & Yes & Yes \\
\hline 22 & URMD/SIL & Urban (medium density) & - & Silt loam & No & No & Yes & No \\
\hline 23 & URMD/SICL & Urban (medium density) & - & Silty clay loam & Yes & No & No & No \\
\hline 24 & URMD/SIC & Urban (medium density) & - & Silty clay & No & Yes & No & No \\
\hline 25 & URMD/C & Urban (medium density) & - & Clay & Yes & Yes & Yes & No \\
\hline 26 & WETL/WA & Wetland/water & - & - & Yes & No & No & No \\
\hline 27 & River Channel & River & - & - & Yes & Yes & Yes & Yes \\
\hline
\end{tabular}

* First two letters indicate cropping system/land use; third and fourth letters indicate crop; letter(s) after the slash indicate soil texture.

$1: 126720$ were obtained from the Manitoba Land Initiative (MLI) database. The soil textures in the sub-catchment were $94 \%$ clay, $4 \%$ silt clay loam, $1 \%$ silt clay, and $1 \%$ silt loam. The land use datasets were acquired from the MLI for non-agricultural land uses and from Agriculture and AgriFood Canada (AAFC) for cropping systems. Cropping systems, or typical cropping rotations, were derived from 9 years (2001-2009) of records from the Manitoba Agricultural Services Corporation (MASC) crop insurance database, as well as land use defined by the Ag-Capture tool between 2009 and 2012 that included each parcel of land in the study area (Yang et al., 2014). The Ag-Capture tool is a geospatial, agricultural land use inventory and mapping tool developed by Agriculture and Agri-Food Canada (OECD, 2013) that validates remote-sensed land use classification using field surveys. The cropping system assigned to each parcel was based on the dominant or most common crop grown, while its representative crop rotation was based on the proportion of the other most common crops grown on the same land parcel over the entire period of record. Cropping systems used in the present model and the crops therein are shown in Table 1.
Using SWAT's watershed delineation tool, the entire La Salle watershed was divided into 38 sub-basins (Fig. 1a) (Yang et al., 2014). The study area was comprised of subbasins 2, 3, 5 and 33; they correspond to the gross drainage area for the gauging station at the outlet of the overall watershed (05OG008; Fig. 1b). The hydrological response units (HRUs) used by CRHM in this study were also based on the HRUs previously defined for the SWAT model (Yang et al., 2014), where HRUs are defined based on unique combinations of land use, soil, and topography. The HRU-definition strategy for applying cropping systems was based on the land use split method (Supplement).

Due to the highly altered nature of the drainage network in the watershed and its low relief, data collection was undertaken to ensure accurate delineation of routing. Initially the stream network was defined based on digital water feature data from the Manitoba Land Initiative (MLI) (1:20 000 Designated Drains) with supplemental ephemeral streams digitized based on aerial photograph interpretation. The drainage ditch dataset, mainly comprised of roadside ditches, utilized a culvert inventory along with lidar DEM 
(vertical accuracy $\pm 0.15 \mathrm{~m}$ ) analysis to determine flow direction to create ditch line segments that passed through culverts and ultimately connected to the stream network. The stream and drainage ditch datasets were merged together to create the final drainage network for the model (Supplement).

\subsection{CRHM module selection}

The Cold Regions Hydrological Modelling platform (CRHM) was used to develop a custom hydrological model for LS-05OG008 (a flow chart summarizing the analysis described in the following sections is provided in the Supplement). CRHM is a modular object-oriented platform that allows the creation of customizable models varying from conceptual to physically based representations of the study area, according to the data availability and uncertainty in process parameters of the basin (Harder and Pomeroy, 2014). A detailed description of CRHM and its modules, which are based on decades of cold-region hydrological research in western and northern Canada, is available in Pomeroy et al. (2007), with an update for agricultural applications in the Canadian Prairies described by Fang et al. (2010). Physically based modules were defined and arranged sequentially to simulate the dominant hydrological processes in LS-05OG008. Table 2 lists the modules selected, their function, and the sequence in which they were entered into the customized model (a chart describing the module structure is provided in the Supplement). Similar model group structures have been successfully used to simulate hydrological processes in the prairie pothole region of the Canadian Prairies (Fang and Pomeroy, 2008; Fang et al., 2010). The same model structure was applied to the four sub-basins of LS-05OG008 (i.e. sub-basins 2, 3, 5 and 33). Each sub-basin was represented in the model by a group, which is a collection of modules executed in sequence for all HRUs and connected with one another by a Muskingum routing group.

\subsection{CRHM module parameterization}

The CRHM software does not make provision for calibration utilizing fitted variables; rather, parameters are selected based on the understanding of the hydrological system (Pomeroy et al., 2007). Since the land use split approach was used, the HRU distribution was held constant over the simulation period, which allowed for a single set of parameters to be used in the model for each HRU. Sub-basin and HRU physiographic parameters (i.e. area, elevation, slope, aspect, and latitude) were obtained from the DEM and HRU reports generated by SWAT during the watershed delineation and HRU definition for a previous SWAT simulation in the La Salle River watershed (Yang et al., 2014). The parameters of the soil and recharge layers (e.g. soil texture, soil porosity, saturated hydraulic conductivity, and water holding capacity) were obtained or derived from the Soil Survey Reports pub- lished by the Province of Manitoba (Michalyna et al., 1972; Ehrlich et al., 1953). The pore size distribution index $(\lambda)$ was defined based on soil textures associated with clay (Brooks and Corey, 1966; Corey, 1994).

Crop seeding dates were defined based on a 10-year average (2000-2009) for each crop based on crop insurance data obtained from MASC. Harvest dates were based on the length of the growing season defined by consultation with farmers in the study area. Leaf area index (LAI), vegetation height, and stalk diameter for the different crops were obtained from the dataset collected by AAFC for the SMAPVEX12 campaign in 2012 (Kim et al., 2014). The SMAPVEX12 field sites were located between 13 and $45 \mathrm{~km}$ south of LS-05OG008 and are located within the Red River watershed in the same or similar ecoregions as the La Salle River watershed (Lake Manitoba Plain or Interlake Plain). The Penman-Monteith method was used to calculate evapotranspiration from crop HRUs, while the Priestley-Taylor method was used to calculate evaporation from open-water HRUs (e.g. wetland, river channel).

Although located in the Canadian Prairies, the runoff routing in the LS-05OG008 sub-catchment does not follow the typical sequence of land uses further west in this region described by Fang et al. (2010) (i.e. fallow, stubble, and pasture routed to woodland and then to wetland, open water, and river channel). Rather, the flat and intensively managed characteristics of the La Salle watershed result in a lack of any typical routing sequence based on land use. For this reason, uplands were routed directly to drainage channels in LS05OG008. For each HRU, the routing length was calculated as the median of the distances from each HRU to the drainage network, as obtained using the "near" tool in ArcGIS 10.1 (ESRI, Redlands, California). The distances to the drainage network were estimated from the 2009 land use coverage using the Ag-Capture tool.

The maximum depression storage of the HRUs was calculated using the methodology described by Fang et al. (2010) for upland areas, where volume and area were calculated from the same lidar DEM used to derive the final drainage network. Briefly, the "fill" tool was used to level off the original DEM and the "cut/fill" tool used to calculate the area and volume from the difference between the original and leveled DEMs. Muskingum routing within and between sub-basins of LS-05OG008 was set up according to Fang et al. (2013). The storage parameter used in the Muskingum routing module was set to 0 , based on the typical pattern observed for regional agricultural runoff monitoring where individual diurnal runoff events at edge-of-field begin as soon as melt starts around noon and stops due to refreezing at night (Tiessen et al., 2010). In-channel storage was calculated as total reach length (calculated in GIS using the drainage network) divided by average flow velocity, which was estimated using measured hydrographs and channel dimensions (i.e. average flow rate in the simulation period divided by cross-sectional area). The dimensionless constant that weights inflow and 
Table 2. Modules used in the customized CRHM to simulate hydrological processes in the LS-05OG008 watershed.

\begin{tabular}{|c|c|c|}
\hline Sequence* & Module & Description \\
\hline 1 & Basin & Holds commonly used physical and control parameters \\
\hline 2 & Solar radiation & $\begin{array}{l}\text { Calculates theoretical global radiation, direct and diffuse solar radiation, as well as maximum } \\
\text { sunshine hours based on latitude, elevation, ground slope, and azimuth (Garnier and Ohmura, } \\
\text { 1970). This module provides radiation input to modules } 3,8 \text {, and } 13 \text {. }\end{array}$ \\
\hline 3 & Observation & $\begin{array}{l}\text { Adjusts the temperature and precipitation variables in the input weather data to variations in } \\
\text { environmental lapse rate, elevation, and wind-induced under-catch }\end{array}$ \\
\hline 4 & Crop growth & Simulates a linear crop development over the growing season \\
\hline 5 & Sunshine hours & $\begin{array}{l}\text { Estimates sunshine hours from incoming short-wave radiation and provides input to modules } 8 \\
\text { and } 13\end{array}$ \\
\hline 6 & Walmsley's windflow & $\begin{array}{l}\text { A parametric version of the wind flow model (Walmsley et al., 1989) that adjusts the wind speed } \\
\text { change due to local topographic features and provides input to module } 11\end{array}$ \\
\hline 7 & Long-wave radiation & $\begin{array}{l}\text { Estimates incoming long-wave radiation from the air temperature and the atmospheric transmit- } \\
\text { tance, which is estimated from measured short-wave radiation and theoretical global radiation } \\
\text { and provides input to module } 13 \text { (Sicart et al., 2006) }\end{array}$ \\
\hline 8 & Summer net radiation & $\begin{array}{l}\text { Estimates the snow-free net all-wave radiation from the calculated short-wave radiation by Gar- } \\
\text { nier and Ohmura (1970) and the caculated net long-wave radiation (Brunt, 1932) using sunshine } \\
\text { hours, air temperature and humidity (Granger and Gray, 1990) and provides inputs to module } 9\end{array}$ \\
\hline 9 & Evaporation & $\begin{array}{l}\text { Estimates actual evapotranspiration from unsaturated surfaces (Monteith, 1965) and evaporation } \\
\text { from saturated surfaces such as stream channels (Priestley and Taylor, 1972). These algorithms } \\
\text { modify the moisture content in the interception, ponded surface water, and soil column stores, } \\
\text { as well as in the stream channel. }\end{array}$ \\
\hline
\end{tabular}

\begin{tabular}{|c|c|c|}
\hline 10 & Canopy & $\begin{array}{l}\text { Estimates the snowfall and rainfall intercepted by the forest canopy, updates the under-canopy } \\
\text { snowfall and rainfall, and calculates short-wave and long-wave sub-canopy radiation (Ellis et } \\
\text { al., 2010) with options for open environments (no canopy adjustment of snow mass and energy) } \\
\text { and forest environments (adjustment of snow mass and energy from the forest canopy) }\end{array}$ \\
\hline 11 & $\begin{array}{l}\text { Prairie Blowing Snow } \\
\text { Model (PBSM) }\end{array}$ & Simulates snow sublimation and transport between HRUs (Pomeroy and Li, 2000) \\
\hline 12 & Albedo & $\begin{array}{l}\text { Estimates the snow albedo during the winter and the melt period (Gray and Landine, 1987). } \\
\text { This module indicates the beginning of melt for module } 13 \text {. }\end{array}$ \\
\hline 13 & $\begin{array}{l}\text { Energy-Budget } \\
\text { Snowmelt } \quad \text { Model } \\
\text { (EBSM) }\end{array}$ & $\begin{array}{l}\text { Estimates snowmelt for snowpack in the Canadian Prairies (Gray and Landine, 1988) by cal- } \\
\text { culating the energy balance of radiation, sensible heat, latent heat, ground heat, advection from } \\
\text { rainfall, and change in internal energy }\end{array}$ \\
\hline 14 & Infiltration & $\begin{array}{l}\text { Estimates snowmelt infiltration into frozen soils (Gray et al., 1985) and rainfall into unfrozen } \\
\text { soils based on texture and ground cover (Ayers, 1959) }\end{array}$ \\
\hline 15 & $\begin{array}{l}\text { Hydraulic conductivity } \\
\text { estimator }\end{array}$ & $\begin{array}{l}\text { Darcy's law for unsaturated flow is used to calculate the drainage factors of module } 16 \text { utilizing } \\
\text { the unsaturated hydraulic conductivity calculated using the Brooks and Corey relationship (Fang } \\
\text { et al., 2013). }\end{array}$ \\
\hline 16 & Soil & $\begin{array}{l}\text { Estimates the soil moisture, groundwater flow, and interactions between groundwater and sur- } \\
\text { face water throughout the year (Leavesley et al., 1983; Dornes et al., 2008; Fang et al., 2010) }\end{array}$ \\
\hline 17 & $\begin{array}{l}\text { Volumetric soil mois- } \\
\text { ture }\end{array}$ & $\begin{array}{l}\text { Converts soil moisture to the volumetric equivalent using the variables from module } 16 \text { and } \\
\text { determines the fall status for module } 14\end{array}$ \\
\hline 18 & Muskingum routing & Routes runoff between HRU and sub-basins using the Muskingum method (Chow, 1964) \\
\hline
\end{tabular}

* Sequence in which the modules were entered into each CRHM group using the Macro window. 
outflow was set to 0.25 , which is a common value for natural stream channels (Carter and Godfrey, 1960).

\subsection{Assessment of model simulations}

Model simulations were graphically and statistically assessed against streamflow data collected by WSC at station number 050G008. The statistical metrics used for model assessment in a daily time step were the Nash-Sutcliffe model efficiency (NSE), model bias (MB), the root mean square difference (RMSD), and the normalized root mean square difference (NMSD) (Fang et al., 2013). Although streamflow simulations were available between 1990 and 2013, some years could not be used for model assessment. Among those are the years of 1990 and 1991, which were used as the model warm-up period, and the years having data quality issues as documented in WSC streamflow database HYDAT (version 10 issued on 17 October 2014). Thus, the years of 19901991, 1997-2001, 2004, and 2008 were not used for model assessment.

Key aspects of the hydrological cycle influencing streamflow generation in cold regions were also used to assess model performance. Simulated snow water equivalent (SWE) was compared to SWE calculated from the depth of snow on ground measured at the Marquette station using the following relationship (Pomeroy and Gray, 1995):

$\mathrm{SWE}=0.01 d_{\mathrm{S}} \rho_{\mathrm{s}}$

where $d_{\mathrm{s}}$ is the depth of snow $(\mathrm{cm}), \rho_{\mathrm{s}}$ is the snow density, which was assumed to be $180 \mathrm{~kg} \mathrm{~m}^{-3}$ based on the typical density range between new and settled snow (Paterson, 1994), and SWE is the same as defined above (mm). Simulated yearly cumulative evaporation from open water was compared to gross evaporation values published for Portage La Prairie between 1992 and 2000 (Martin, 2002), which is the closest location with available data corresponding to the time period of model simulations. Since both values were based on evaporation models and not measured, the evaporation comparison was made only to verify that CRHM simulations were in agreement with values expected for the study area. Simulated volumetric soil water content (VWC, expressed in $\mathrm{mm}$ of water in the soil profile, i.e. VMC $\left(\mathrm{m}^{3} \mathrm{~m}^{-3}\right) \times$ profile depth $\left.(\mathrm{mm})\right)$ was compared to VWC simulated across Canada using the National Drought Model (NDM) (Chipanshi et al., 2013). Similarly to evaporation, no direct measurements of soil moisture were available in close proximity to the watershed; thus, the NDM dataset was used to verify only whether the VWC simulated by CRHM was within a reasonable range and followed the expected seasonal trend.

\subsection{Sensitivity analysis}

In order to assess the suitability of a single storage parameter (K storage) in the Muskingum model for wet and dry years, a sensitivity analysis was carried out for both overland and drainage network HRUs. In the analysis, the $\mathrm{K}$ storage parameter was varied to $0,1,2,4,8$, and 15 days for the upland HRUs and to $0,1,2,2.5,3,4,8,15$, and 20 days for the river network. The sensitivity of the model performance to $\mathrm{K}$ storage was done through a graphical assessment of NSE and $\mathrm{MB}$ with variations of that variable.

\subsection{Model falsification}

Taking advantage of the flexible structure of the CRHM platform to simulate physically based hydrological processes, model falsifications were performed to assess the impact of snow sublimation, blowing snow (which includes both snow sublimation and transport), and frozen-soil infiltration on stream discharge in the study area. These processes are typical of the Canadian Prairies and very influential in runoff generation in the region (Pomeroy et al., 2007). A stepwise model falsification was achieved by sequentially removing the following processes from the model: (i) snow sublimation, (ii) blowing snow, (iii) frozen-soil infiltration, and (iv) blowing snow and frozen-soil infiltration, which is the combination of cases (ii) and (iii). The impact of model falsification was assessed for water years (1 October-30 September of the following year) rather than the calendar year, since a complete time series was available from model simulations. However, statistical metrics used for model assessment (i.e. NSE and MB) were only calculated between March and October, which is the period for which observed streamflow was available.

\section{Results}

\subsection{Flow characteristics in the study area between 1990 and 2013}

As is typical of the cold-region conditions prevailing in the Canadian Prairies, no major snowmelt events occur in the La Salle River over the winter, and peak stream discharge usually takes place in the spring (Table 3). Thirteen out of 15 years exhibited annual peak discharge with snowmelt. The median peak discharge was $6.7 \mathrm{~m}^{3} \mathrm{~s}^{-1}$, while the median annual discharge volume was $1.25 \times 10^{7} \mathrm{~m}^{3}$ and the median water yield was $66 \mathrm{~mm}$. Years with peak discharge above the median corresponded to years with annual discharge volume above the median, due to the strong positive correlation between these two variables $\left(r^{2}=0.90\right)$, reflecting the fact that most of the annual discharge occurs during spring and is associated with event runoff rather than baseflow. Those years with peak discharge and annual discharge volume equal to or above median values were considered wet years for model assessment purposes and include the years of 1996, 2005, 2006, 2009-2011, and 2013.

Seven out of 15 years had ice conditions at time of peak discharge, while 2 years had peak discharges 1 day after the 
Table 3. Streamflow characteristics of the study area for the years used in the analysis.

\begin{tabular}{|c|c|c|c|c|c|c|c|c|}
\hline \multirow[b]{2}{*}{ Year } & \multirow[b]{2}{*}{$\begin{array}{r}\text { Water } \\
\text { yield }(\mathrm{mm})\end{array}$} & \multicolumn{5}{|c|}{ Discharge } & \multirow[b]{2}{*}{ Ice conditions } & \multirow[b]{2}{*}{ Backwater } \\
\hline & & $\begin{array}{r}\text { Annual }^{2} \\
\left(\mathrm{~m}^{3}\right)\end{array}$ & $\begin{array}{r}\text { Snowmelt } \\
\left(\mathrm{m}^{3}\right)\end{array}$ & $\begin{array}{r}\text { Snowmelt } \\
\text { proportion }(\%)\end{array}$ & $\begin{array}{r}\text { Peak } \\
\left(\mathrm{m}^{3} \mathrm{~s}^{-1}\right)\end{array}$ & $\begin{array}{l}\text { Peak } \\
\text { date }\end{array}$ & & \\
\hline 1992 & 64 & $1.21 \times 10^{7}$ & $7.27 \times 10^{6}$ & 60 & 6.7 & 10 April & 1 March-12 April & No data for analysis \\
\hline 1993 & 66 & $1.25 \times 10^{7}$ & $4.51 \times 10^{6}$ & 36 & 5.6 & 7 April & 1 March-10 April & No data for analysis \\
\hline 1994 & 18 & $3.33 \times 10^{6}$ & $9.32 \times 10^{5}$ & 28 & 0.7 & 10 April & 1 March-16 April & No data for analysis \\
\hline 1995 & 61 & $1.15 \times 10^{7}$ & $6.56 \times 10^{6}$ & 57 & 5.0 & 31 March & 1 March-15 April & No data for analysis \\
\hline 1996 & 99 & $1.87 \times 10^{7}$ & $1.35 \times 10^{7}$ & 72 & 13.5 & 29 April & 1 March-28 April & No data for analysis \\
\hline 2002 & 10 & $1.94 \times 10^{6}$ & $1.94 \times 10^{6}$ & 100 & 1.6 & 16 April & 1 March-16 April & No backwater \\
\hline 2003 & 18 & $3.49 \times 10^{6}$ & $3.49 \times 10^{6}$ & 100 & 2.1 & 2 April & 1 March-9 April & No backwater \\
\hline $2005^{1}$ & 83 & $1.57 \times 10^{7}$ & $4.54 \times 10^{6}$ & 29 & 10.0 & 8 April & 1 March-4 April & $\begin{array}{l}\text { 3-14 April } \\
29 \text { June-24 July }\end{array}$ \\
\hline 2006 & 115 & $2.18 \times 10^{7}$ & $2.18 \times 10^{7}$ & 100 & 16.5 & 10 April & 1 March-7 April & 3-19 April \\
\hline 2007 & 38 & $7.26 \times 10^{6}$ & $7.26 \times 10^{6}$ & 100 & 4.6 & 12 April & 1 March-5 April & 31 March-13 April \\
\hline 2009 & 89 & $1.69 \times 10^{7}$ & $1.69 \times 10^{7}$ & 100 & 13.3 & 17 April & 1 March-16 April & 11-26 April \\
\hline 2010 & 110 & $2.09 \times 10^{7}$ & $1.04 \times 10^{7}$ & 50 & 10.7 & 1 June & 1 March-5 April & $\begin{array}{l}30 \text { May-6 June } \\
2-3 \text { September }\end{array}$ \\
\hline 2011 & 150 & $2.84 \times 10^{7}$ & $1.59 \times 10^{7}$ & 56 & 15.7 & 13 April & 1 March-13 April & $\begin{array}{l}\text { 4-20 April } \\
\text { 20-21 May }\end{array}$ \\
\hline 2012 & 26 & $4.89 \times 10^{6}$ & $1.71 \times 10^{6}$ & 35 & 2.5 & 29 May & 1-24 March & No backwater \\
\hline 2013 & 76 & $1.44 \times 10^{7}$ & $9.38 \times 10^{6}$ & 65 & 9.4 & 4 May & 1 March-1 May & 28 April-8 May \\
\hline
\end{tabular}

${ }^{1}$ Backwater issues late in the summer; ${ }^{2}$ total flow from 1 March to 31 October.

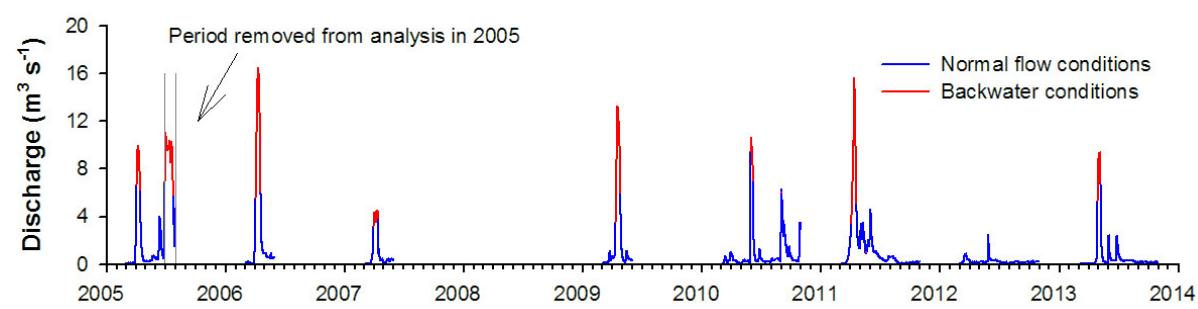

Figure 2. Yearly hydrographs indicating periods of potential backwater issues. The years of 2002 and 2003 are not presented since these years did not have backwater issues. The years of 2004 and 2008 were not included in the analysis since quality issues were identified in the metadata of the records. The periods between lines in 2005 indicate the records removed from the dataset during model assessment.

end of the ice period (Table 3). Ice conditions at peak discharge were most common in years with cumulative and peak discharges equal to or below the median. Field observations at the site indicate that the absence of ice in wet years was likely due to faster-moving water at high discharge. However, ice moving downstream still may have impacted the flow regime at the gauging station through the formation of ice jams along the river channel and promotion of backwater conditions, which were relatively common (Table 3 ).

Seven out of 9 years with both upstream and downstream level monitoring exhibited potential backwater effects (Table 3; Fig. 2). Potential backwater events were generally more associated with years of high discharges. Backwater in this reach could be caused by two factors, the first being the confluence of the Elm River channel and the La Salle River just downstream of gauging station 05OG008 (Fig. 1b). Given the gentle topographic gradient of the area and the presence of the water level control structure, the water backs up in the reach of the La Salle River upstream of the confluence of the two channels. The second factor is the occurrence of ice-damming and potential for buildup from the $4 \mathrm{~m}$ dam at Starbuck located $28.6 \mathrm{~km}$ downstream following an elevation change of $3 \mathrm{~m}$.

\subsection{CRHM simulations of stream discharge}

The majority of annual stream discharge occurs in spring and in particular with snowmelt, making this the most important period for hydrological simulations to identify nutrient export potential (Table 3 ). However, stream discharge measurements during the spring are also associated with the greatest potential for model and measurement uncertainties related to ice conditions and backwater issues. Given the hydrological importance of stream discharges driven by snowmelt, 

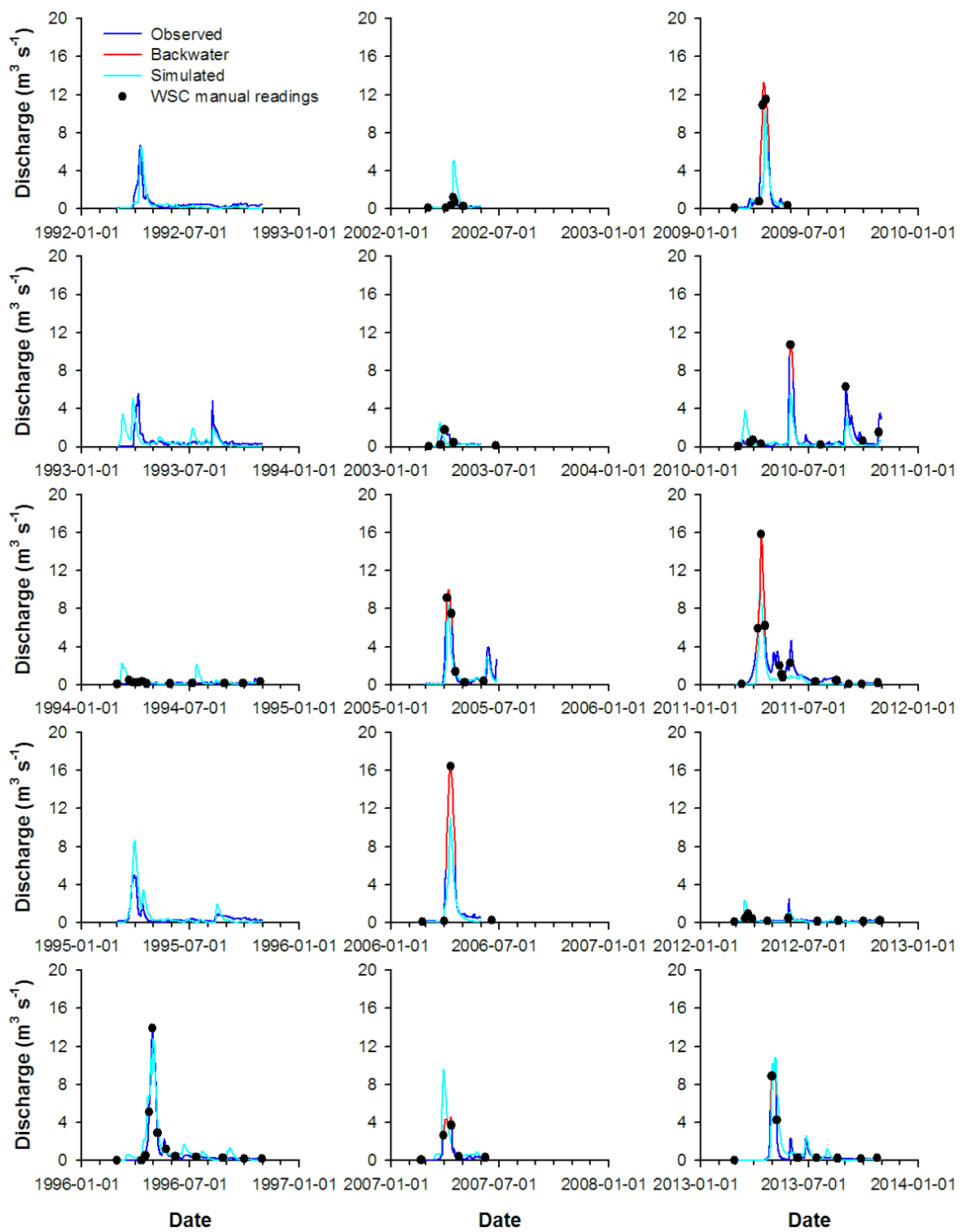

Figure 3. Comparison of observed and simulated stream discharge between 1992 and 2013 for years with good records in the HYDAT database.

model assessment was performed without removing questionable spring records from the dataset. The only period removed from analysis was the backwater period in July of 2005 that occurred following an extreme rainfall runoff event (Table 3; Fig. 2) with a high degree of known uncertainty regarding measurement accuracy caused by backwater and debris buildup (according to WSC field notes), and representing disinformation for model assessment (Beven, 2011).

Graphical comparison between observed and simulated stream discharge indicates that the model skill varied for different years (Fig. 3). Records of discharge measurements performed by WSC during site visits were obtained and are also shown in Fig. 3. Simulated time of peak discharge was generally in good agreement with observed values, except for 3 out of 15 years (i.e. 1993, 2003, and 2007). These 3 years had peak discharge and annual discharge volume equal to or below the medians for the $1990-2013$ period (i.e. $6.7 \mathrm{~m}^{3} \mathrm{~s}^{-1}$ for peak discharge and $1.25 \times 10^{7} \mathrm{~m}^{3}$ for annual discharge volume). The magnitude of peak discharges was also reasonably simulated by the model (Fig. 4), although with more variability than timing of peak. Much of this variation was associated with years of discharge volume below the median (i.e. 1994, 1995, 2002, and 2007) or large peak discharge (i.e. 2006, 2009, and 2011). There was no direct relationship between overestimation of simulated peak discharges (Fig. 4) and overestimation of annual discharge volumes (Fig. 5). 


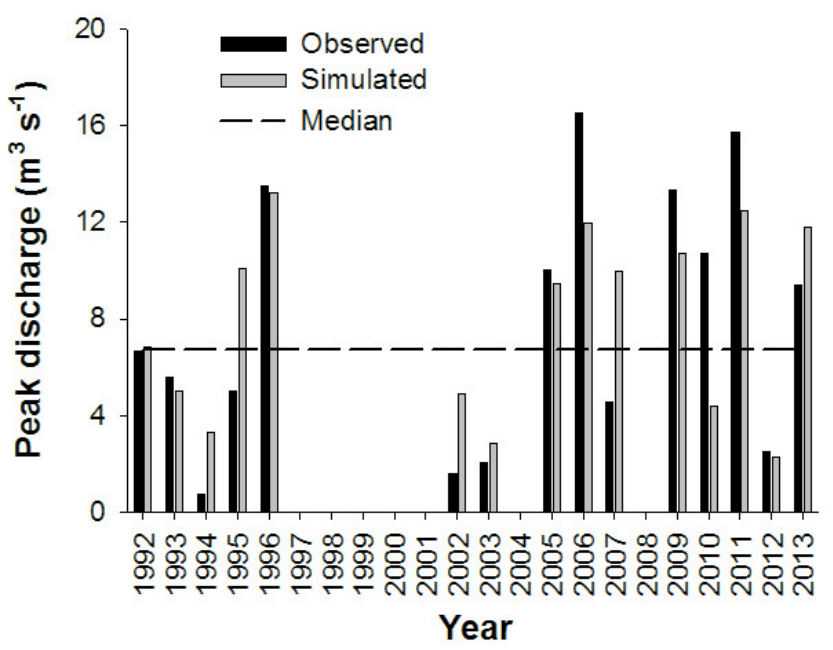

Figure 4. Comparison of observed and simulated peak discharge between 1992 and 2013 for years with good records in the HYDAT database. No data available in the HYDAT database between 1997 and 2001. The years of 2004 and 2008 were not included in the analysis since quality issues were identified in the metadata of the records.

However, there was a tendency for simulated annual discharge volumes to be overestimated in low-discharge years (Fig. 5) and to underestimate large peak discharges (Fig. 4).

Statistical metrics used to assess model performance are shown in Table 4. The results confirm the trends shown in graphical analysis where the model had very good performance for years with peak discharge equal to or larger than the median peak discharge. The Nash-Sutcliffe efficiency (NSE) was consistently above 0.65 and averaged 0.76 for 1992, 1996, 2005, 2006, 2009, 2011, and 2013. The year 2010 was an exception, with NSE $=0.36$. For low discharge years, NSE was negative, indicating that the model was no better than utilizing mean discharge as a predictor of stream discharge. For the years with NSE $>0.65$, the model bias (MB) was generally negative, although the average model bias was small (i.e. $5 \%$ ). This was likely due to the overall underestimation of peak discharges during those years. Conversely, MB was generally positive for years with negative NSE, which correspond to years with annual discharge volumes below the 1990-2013 median. This confirms the difficulty in simulating low discharges as was observed in the graphical analysis. The root mean square difference (RMSD) and the normalized root mean square difference (NRMSD) were small to moderate, given the range of discharges comprised between minimum and peak discharges.

\subsection{CRHM simulation of SWE, evaporation, and VWC}

The annual trend in SWE and time of melt was accurately captured by the model (Fig. 6). Differences in peak SWE (e.g. 1992 and 1996) were likely due to inter-annual varia-
Table 4. Metrics used for model assessment.

\begin{tabular}{rrrrr}
\hline Year & NSE & MB & RMSD & NRMSD \\
\hline 1992 & 0.69 & -0.10 & 0.51 & 0.89 \\
1993 & -0.79 & 0.31 & 1.13 & 1.92 \\
1994 & -27.91 & 2.00 & 0.68 & 4.31 \\
1995 & -0.58 & 0.81 & 1.10 & 2.02 \\
1996 & 0.81 & 0.50 & 1.00 & 1.14 \\
2002 & -14.04 & 2.01 & 0.96 & 3.92 \\
2003 & -1.08 & 0.16 & 0.69 & 1.58 \\
2005 & 0.85 & -0.12 & 0.93 & 0.77 \\
2006 & 0.76 & -0.38 & 2.31 & 0.84 \\
2007 & -0.43 & 0.69 & 1.65 & 1.81 \\
2009 & 0.65 & -0.31 & 2.18 & 1.02 \\
2010 & 0.36 & -0.26 & 1.50 & 1.52 \\
2011 & 0.84 & -0.29 & 0.98 & 0.73 \\
2012 & -0.60 & 0.30 & 0.27 & 1.16 \\
2013 & 0.72 & 0.36 & 0.91 & 1.34 \\
\hline
\end{tabular}

tion in snow density, which was not measured and can vary substantially with space and time (Pomeroy and Gray, 1995). However, the assumed snow density value did not introduce a substantial bias into SWE estimation, as most years had good agreement between simulated and observed peak SWE values. CRHM was also able to simulate cumulative open water evaporation that compared well with gross evaporation estimates for the years when data were available (Fig. 7). The average cumulative gross evaporation estimated by AAFC at Portage La Prairie was $686 \mathrm{~mm}$, while that simulated by CRHM for open water was $682 \mathrm{~mm}$. The soil moisture variation trend over the year was also well simulated by CRHM in most years (Fig. 8). CRHM was generally able to capture the trend in soil moisture content at the beginning of each growing season and to mimic its depletion and recovery over the course of the summer and fall seasons, respectively. Larger departures from the AAFC data in soil moisture occurred in dry years (e.g. 1995, 2003, and 2012). The results above are important since they imply that antecedent conditions were reasonably well predicted, especially in wet years, with accurate representation of watershed hydrological processes, and that soil infiltration, soil freezing, and snowmelt runoff patterns can be modelled with greater confidence.

\subsection{Sensitivity analysis using the storage parameter in the Muskingum model}

A sensitivity analysis was carried out using the storage parameter in the Muskingum model (K storage) for both overland and drainage network flow routing to investigate the adequacy of average values for both wet and dry years (Fig. 9). For wet years, the plot indicates equifinality (Beven, 2011), where different models have similar performance when $\mathrm{K}$ storage is in the range between 0 and 4 days for both upland areas and drainage networks (Fig. 9a). The model bias for peak flows aids model selection by defining a narrow band 

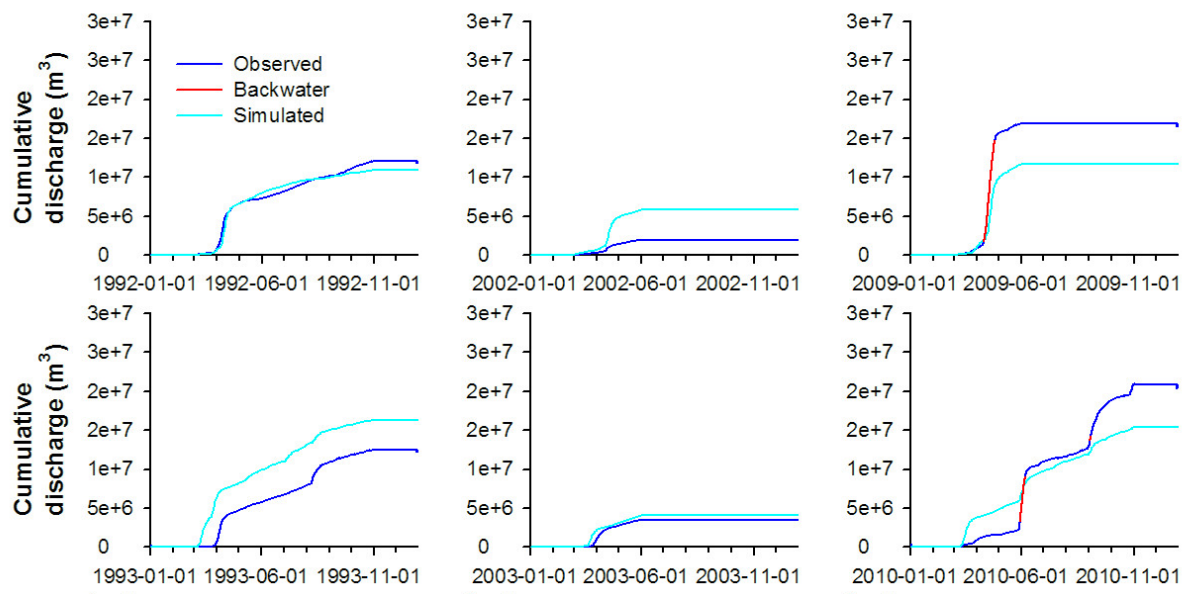

-01-01 2002-06-01 2002-11-01

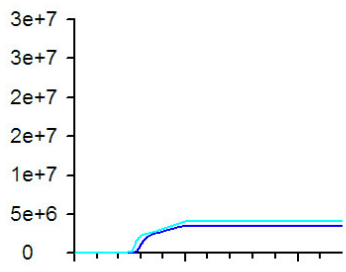

3e+7 $2009-01-012009-06-012009-11-0$

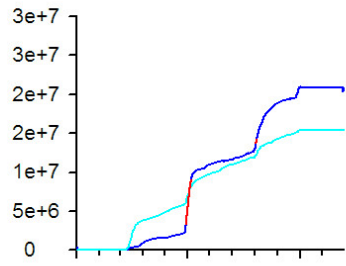

2003-01-01 2003-06-01 2003-11-01

$3 e+7$
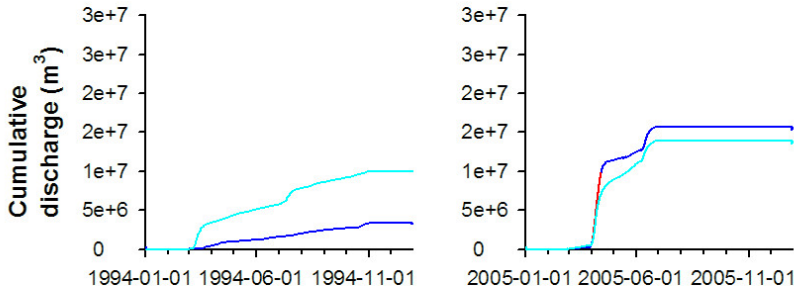

2010-01-01 2010-06-01 2010-11-01

$3 e+7$

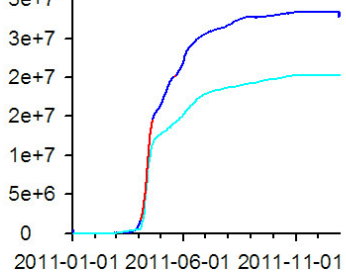

$3 e+7$

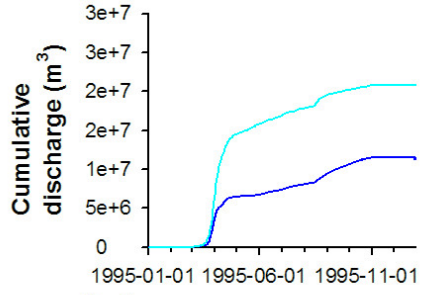

$3 e+7$

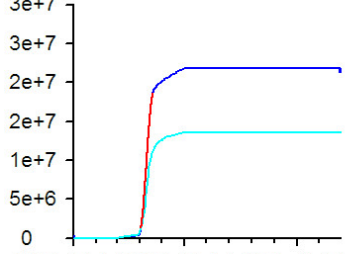

2006-01-01 2006-06-01 2006-11-01

$3 e+7$
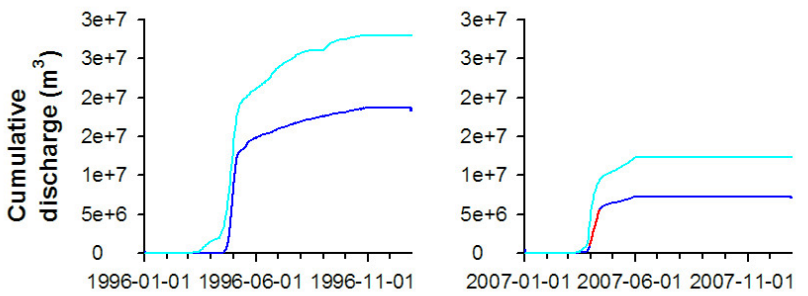

2007-01-01 2007-06-01 2007-11-01

Date

Date

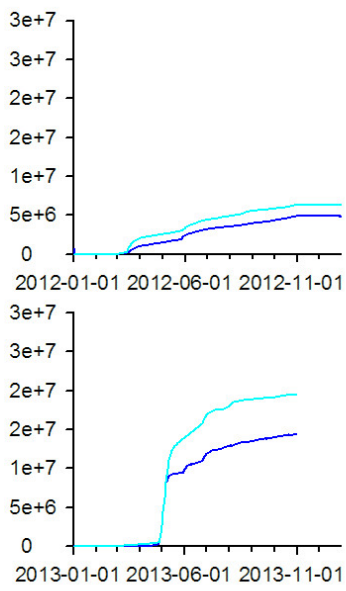

Date

Figure 5. Comparison of observed and simulated annual cumulative discharge between 1992 and 2013 for years with good records in the HYDAT database.

for which the bias is minimized (Fig. 9c). However, knowledge of the flow characteristics is still necessary to define the $\mathrm{K}$ storage parameter. In this case, $\mathrm{K}$ storage of 0 and 3 days for upland areas and drainage networks, respectively, seems reasonable to maximize NSE and minimize peak-flow MB. Conversely, the model performance for dry years tends to improve as $\mathrm{K}$ storage increases for both upland areas and drainage networks, although NSE is still in the negative range (Fig. 9b). The contour plot of peak-flow model bias for dry years also suggests large $\mathrm{K}$ storage values since low bias is only found for higher K storage values (Fig. 9d).

Despite the relative improvement, changing $\mathrm{K}$ storage in dry years did not impact model performance appreciably. These results may suggest that the hydrological controls un- der dry conditions in this watershed are not strongly topological (i.e. drainage network) but typological (i.e. landscape elements) (Buttle, 2006). In order to assess this possibility, the CRHM option to allow infiltration prior to the major melt event was selected in an attempt to emulate the effect of preferential flow. The NSE and MB for dry years were, respectively, -27.87 and 2.0 (1994), -0.58 and 0.81 (1995), -9.6 and 1.7 (2002), -1.09 and 0.16 (2003), -0.43 and 0.69 (2007), and -0.17 and 0.25 (2012). These results indicate a potential influence of infiltration prior to the major melt event (used here as a proxy for preferential flow) on model performance in 2 out of 6 years (i.e. 2002 and 2012) when compared to the based model (Table 4). Inclusion of this process in the model structure improved predic- 

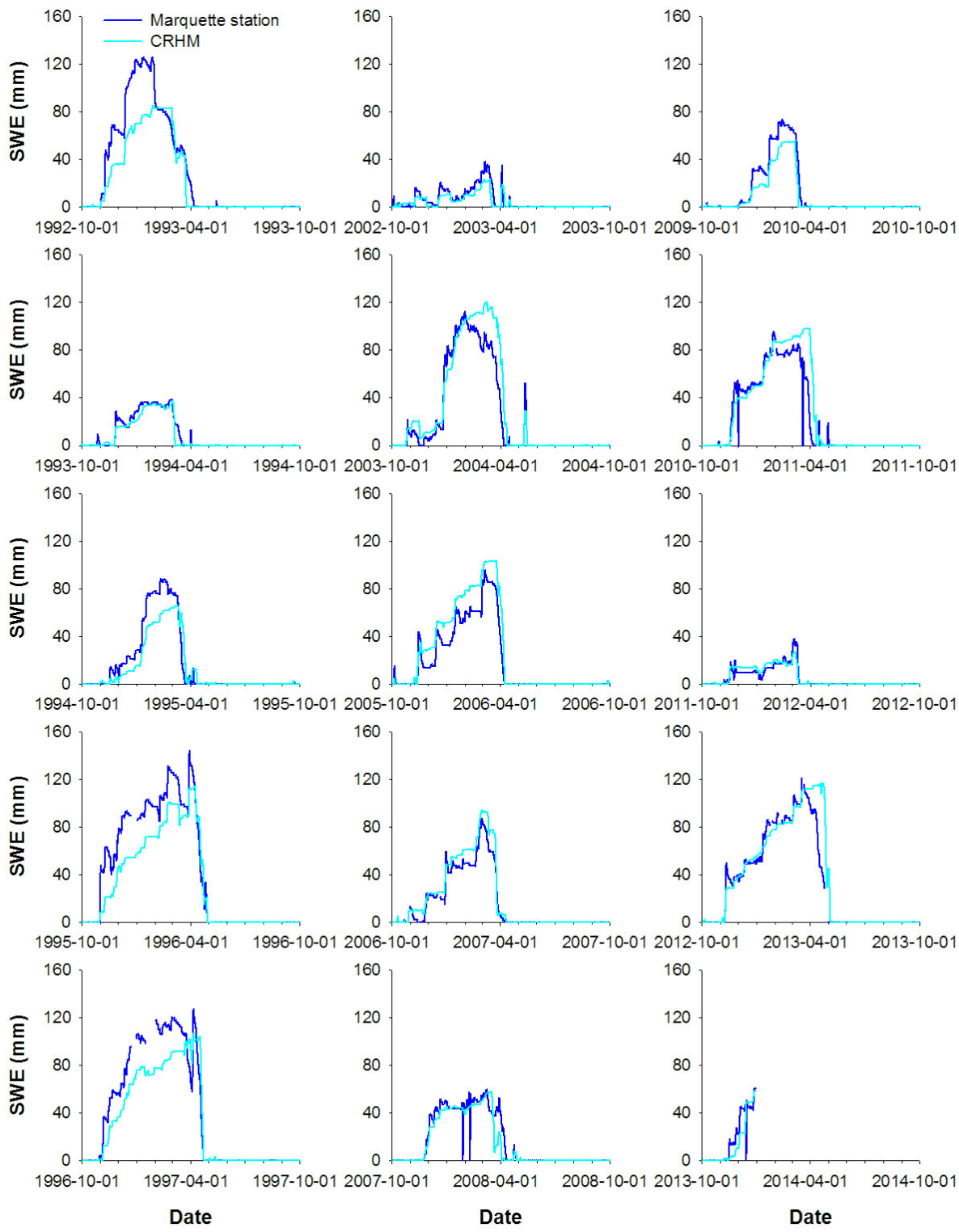

Figure 6. Comparison of observed and simulated snow water equivalent (SWE) between 1992 and 2013 for years with good records in the HYDAT database. SWE was calculated assuming a snow density of $180 \mathrm{~kg} \mathrm{~m}^{-3}$.

tions more than $30 \%$ of the time, although NSE values were still negative in all cases. However, processes other than infiltration could also be influencing model performance, such as an enhanced role of depressional storage.

\subsection{Model falsification}

Comparison of the hydrographs between the base model and the falsified models indicates that sublimation, blowing snow, and infiltration to frozen soils are influential processes in the study area (Fig. 10). Turning off snow sublimation and blowing snow (i.e. snow sublimation and transport combined) in the models resulted in increased peak discharges (Fig. 10c-d), while removing frozen-soil infiltration reduced peak discharge with or without blowing snow (Fig. 10ef). The average change in peak discharge due to sublimation inhibition increased by $25.4 \%$, while the increase due to blowing snow inhibition was $39.1 \%$; the effect of inhibiting frozen-soil infiltration was the opposite, with reductions around $60 \%$ in peak discharge regardless of the blowing snow process (Table 5). Despite the average increase in peak discharge, there were also reductions in peak discharge in particular years when the snow sublimation and blowing snow were removed (i.e. 1993-1994, 1994-1995, 20032004, and 2006-2007). For frozen-soil infiltration models, removing this process had a very consistent effect on peak discharge, with reductions in all but 1 year (i.e. 2001-2002). 
Table 5. Percent change in peak discharge, total discharge, and snow water equivalent (SWE) between falsified models and base models.

\begin{tabular}{|c|c|c|c|c|c|c|c|c|c|c|c|c|}
\hline \multirow[b]{2}{*}{$\begin{array}{l}\text { Water } \\
\text { year }\end{array}$} & \multicolumn{3}{|c|}{ Snow sublimation } & \multicolumn{3}{|c|}{ Blowing snow } & \multicolumn{3}{|c|}{ Frozen-soil infiltration } & \multicolumn{3}{|c|}{$\begin{array}{l}\text { Frozen-soil infiltration } \\
\text { and blowing snow }\end{array}$} \\
\hline & $\begin{array}{r}\text { Peak } \\
\text { discharge }\end{array}$ & $\begin{array}{r}\text { Total } \\
\text { discharge }\end{array}$ & SWE & $\begin{array}{r}\text { Peak } \\
\text { discharge }\end{array}$ & $\begin{array}{r}\text { Total } \\
\text { discharge }\end{array}$ & SWE & $\begin{array}{r}\text { Peak } \\
\text { discharge }\end{array}$ & $\begin{array}{r}\text { Total } \\
\text { discharge }\end{array}$ & SWE & $\begin{array}{r}\text { Peak } \\
\text { discharge }\end{array}$ & $\begin{array}{r}\text { Total } \\
\text { discharge }\end{array}$ & SWE \\
\hline $1992-1993$ & 39.4 & 12.3 & 23.0 & 69.5 & 7.1 & 23.0 & -65.7 & -2.8 & 0.0 & -65.0 & -5.3 & 23.0 \\
\hline 1993-1994 & -3.8 & 2.1 & 24.8 & -2.0 & -2.4 & 24.8 & -34.6 & 18.4 & 0.0 & -34.4 & 24.4 & 24.8 \\
\hline 1994-1995 & -11.3 & -1.9 & 41.8 & -13.1 & -1.5 & 41.8 & -77.9 & -24.3 & 0.0 & -78.1 & -25.3 & 41.8 \\
\hline 1995-1996 & 24.3 & 8.7 & 39.5 & 47.4 & 5.3 & 39.5 & -78.5 & -29.2 & 0.0 & -82.1 & -38.0 & 39.5 \\
\hline 1996-1997 & 180.1 & 45.7 & 39.7 & 350.5 & 47.3 & 39.7 & -32.7 & 8.4 & 0.0 & -43.1 & -12.5 & 39.7 \\
\hline 1997-1998 & 29.5 & 11.4 & 19.9 & 33.6 & -1.3 & 19.9 & -75.5 & 5.4 & 0.0 & -75.4 & 5.3 & 19.9 \\
\hline 1998-1999 & 7.3 & 4.9 & 62.8 & 3.1 & -2.4 & 62.8 & -42.4 & 43.4 & 0.0 & -41.8 & 46.0 & 62.8 \\
\hline 1999-2000 & 14.3 & 4.8 & 30.4 & 14.6 & 1.6 & 30.4 & -41.4 & 8.1 & 0.0 & -41.3 & 7.2 & 30.4 \\
\hline 2000-2001 & 19.0 & 17.0 & 13.9 & 16.0 & 18.4 & 13.9 & -79.7 & -12.8 & 0.0 & -79.7 & -17.9 & 13.9 \\
\hline 2001-2002 & 25.1 & 10.3 & 22.0 & 30.5 & 3.4 & 22.0 & 21.9 & 13.7 & 0.0 & 24.0 & 12.6 & 22.0 \\
\hline $2002-2003$ & 17.0 & 6.1 & 151.3 & 23.8 & -1.9 & 151.3 & -72.6 & 42.7 & 0.0 & -72.2 & 44.1 & 151.3 \\
\hline 2003-2004 & -8.2 & 9.2 & 17.3 & -1.3 & 16.3 & 17.3 & -80.1 & -21.3 & 0.0 & -79.8 & -26.0 & 17.3 \\
\hline 2004-2005 & 30.4 & 9.1 & 19.4 & 27.5 & 2.2 & 19.4 & -60.0 & -7.1 & 0.0 & -60.0 & -12.4 & 19.4 \\
\hline $2005-2006$ & 16.2 & 8.9 & 22.3 & 10.5 & 1.0 & 22.3 & -89.8 & -27.0 & 0.0 & -92.4 & -30.8 & 22.3 \\
\hline 2006-2007 & -4.0 & 18.9 & 28.7 & -4.0 & 9.6 & 28.7 & -84.7 & -11.1 & 0.0 & -84.5 & -15.0 & 28.7 \\
\hline 2007-2008 & 99.3 & 15.4 & 53.0 & 89.3 & -4.5 & 53.0 & -52.0 & 14.5 & 0.0 & -62.3 & 10.0 & 53.0 \\
\hline 2008-2009 & 36.5 & 10.7 & 16.2 & 49.1 & 5.2 & 16.2 & -80.4 & -4.1 & 0.0 & -76.2 & -2.7 & 16.2 \\
\hline 2009-2010 & 1.7 & -0.6 & 23.6 & 22.3 & -5.8 & 23.6 & -36.1 & 6.6 & 0.0 & -37.0 & 5.8 & 23.6 \\
\hline 2010-2011 & 2.9 & 6.5 & 19.6 & 21.8 & 5.6 & 19.6 & -80.7 & -18.8 & 0.0 & -83.8 & -24.7 & 19.6 \\
\hline 2011-2012 & 16.1 & 5.0 & 54.2 & 4.0 & -2.2 & 54.2 & -53.8 & 36.9 & 0.0 & -53.2 & 38.9 & 54.2 \\
\hline 2012-2013 & 2.5 & 2.3 & 13.1 & 28.0 & 5.6 & 13.1 & -79.5 & -29.4 & 0.0 & -82.8 & -34.3 & 13.1 \\
\hline Average & 25.4 & 9.8 & 35.1 & 39.1 & 5.1 & 35.1 & -60.8 & 0.5 & 0.0 & -62.0 & -2.4 & 35.1 \\
\hline
\end{tabular}

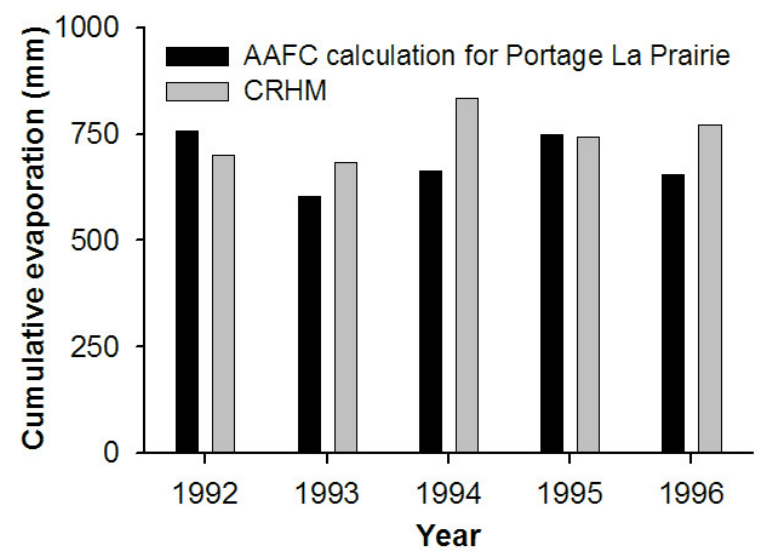

Figure 7. Comparison of evaporation estimates produced by the Agriculture and Agri-Food Canada (AAFC) and CRHM between 1992 and 1996.

One striking effect of the model falsification was that disrupting snow sublimation, blowing snow, and frozen-soil infiltration caused a disconnection between peak discharge and annual discharge, which was a feature of the observed stream discharge (Sect. 3.1). In some years, reductions in peak discharge were accompanied by increases in total discharge (e.g. 2003-2004 for snow sublimation and blowing snow falsifications; 2002-2003 for frozen-soil infiltration models). In other years, the opposite was true (e.g. 2009-2010 for snow sublimation and blowing snow falsifications; no instances for frozen-soil infiltration models; Table 5).

Models with snow processes disrupted also presented consistent increases in SWE over the entire simulation period (Table 5). Notably, there was no difference in SWE percent change among the models with snow sublimation and blowing snow falsifications, which indicates no influence of snow transport on SWE. No transport of snow out of the watershed was confirmed by assessing the snow loss variable within CRHM, which indicated total losses smaller than $1 \mathrm{~mm}$ over the 21 years of simulation (i.e. including the spin-up years) in all cases.

The statistical metrics calculated for the falsified models (Table 6) confirmed the loss of model performance when compared to the base model (Table 4), which highlights the importance of snow sublimation, blowing snow, and infiltration to frozen-soil processes for accurately simulating stream discharge in the study area. Models with falsified snow processes (i.e. snow sublimation and blowing snow) generally presented a loss of performance, although in specific years, performance remained comparable (e.g. 2010) or improved slightly (e.g. 2005, 2006). This improvement was likely due to the increased peak discharge that offset the trend of the model to underestimate large peak discharges in wet years (Fig. 4). Similarly to NSE, model bias tended to become more extreme due to falsification of snow processes.

Loss of performance was observed with falsification of frozen-soil infiltration (including blowing snow falsification 

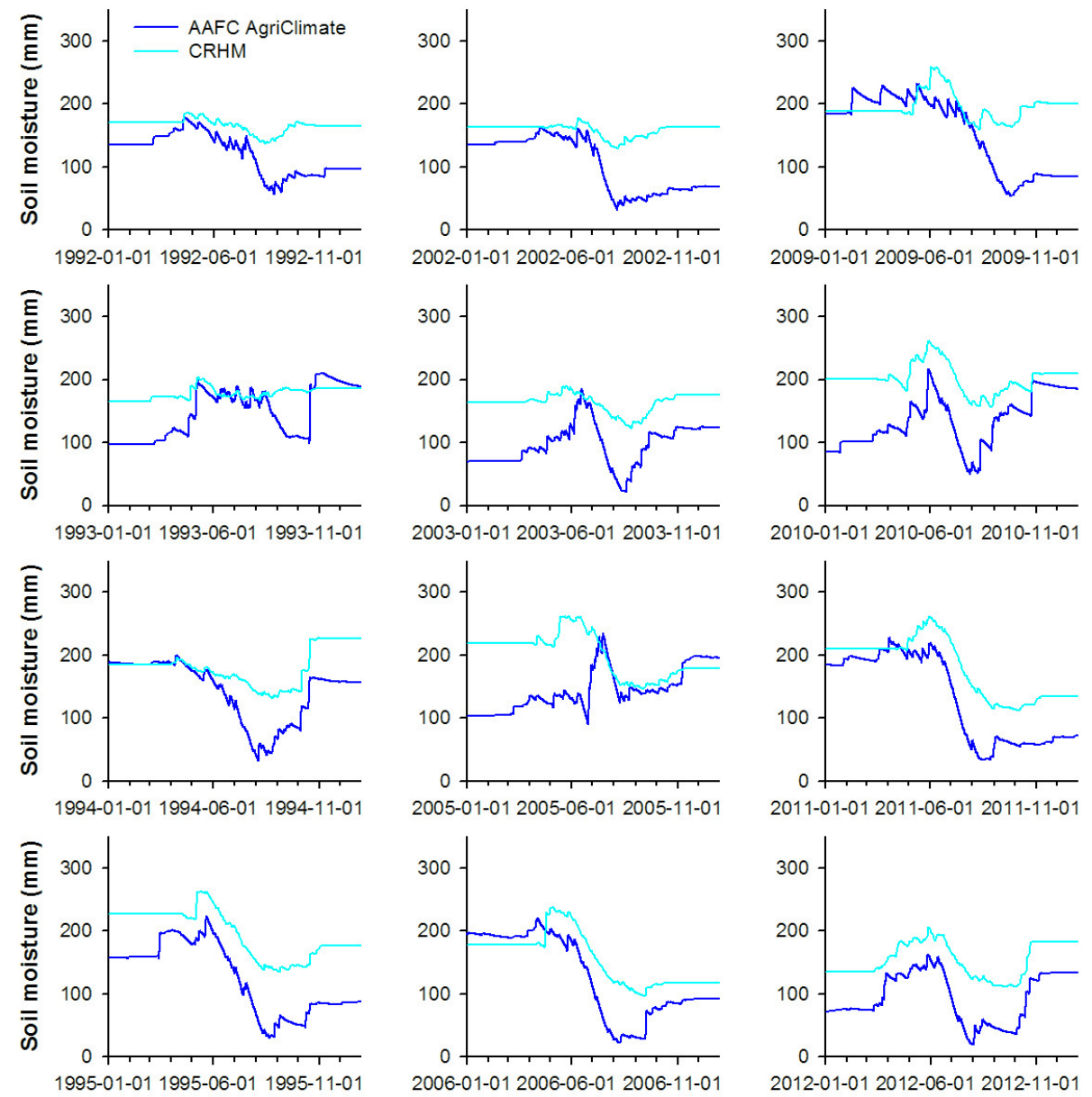

2011-01-01 2011-06-01 2011-11-01
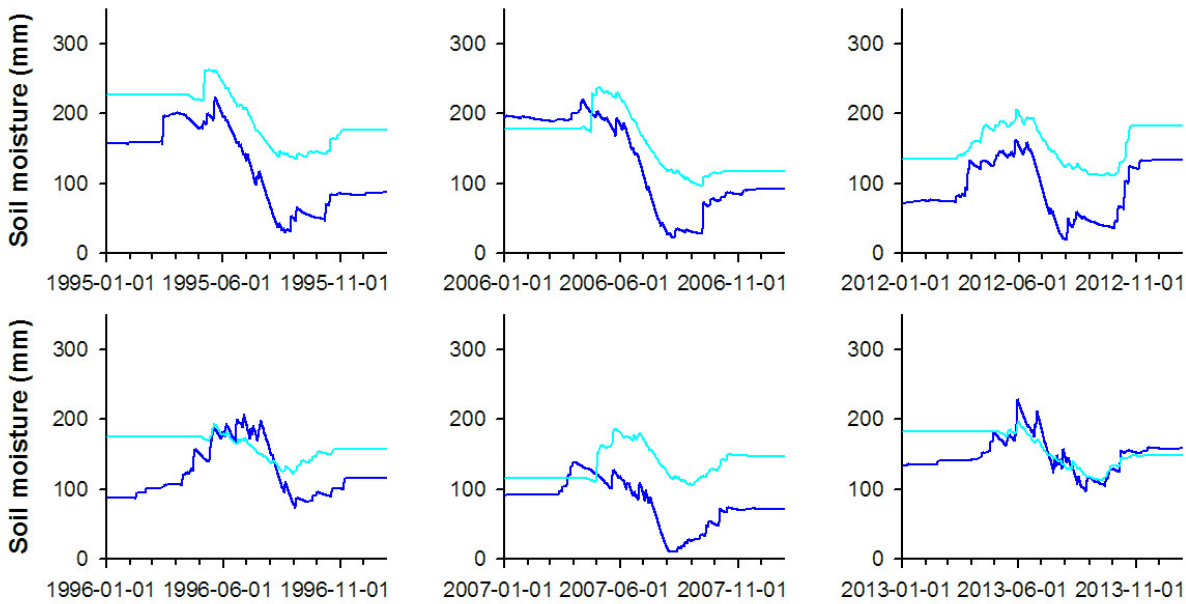

Date

Date

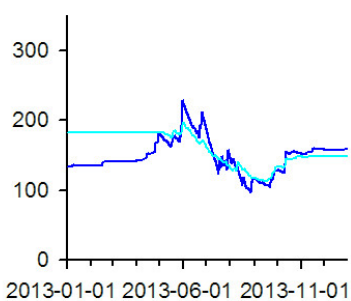

Date

Figure 8. Comparison between simulated volumetric soil water content (VWC; expressed in mm of water in the soil profile) produced by the National Drought Model (NDM) and CRHM between 1992 and 2013 for years with good records in the HYDAT database.

or not) in relation to the base model and was more severe in wet years due to drastic reduction in peak discharge (Fig. 10). However, performance tended to improve in dry years (e.g. 2005), which was likely due to an offset in the trend of the base model to overestimate discharges in those years. Reduced peak and total discharges due to falsification of the frozen-soil infiltration process were due to increased infiltration.

\section{Discussion}

\subsection{Stream discharge uncertainty}

The assessment of the hydrological records of the La Salle River at gauging station 050G008 suggests that ice and backwater pose additional challenges to simulating streamflow in the study area. Peak flows in the river usually took place under ice-impacted conditions or directly after clearing of ice (Table 3), which may have impacted both the accuracy of discharge measurements at the site (Environment and Climate Change Canada, 2015b) and hydrograph patterns. Com- 
ments from WSC field notes identified a number of potential sources of uncertainty for discharge measurements. For example, backwater conditions are reported in 2005, 2010, and 2011, which correspond to the period of backwater identified in this study. Overbank flow into the riparian vegetation is reported for 2007, which also corresponds to the backwater period identified in the present analysis.

Backwater during ice conditions may take place because the bottom of the ice cover causes an increase in flow resistance (Gray and Prowse, 1993) and may affect flow magnitudes and timing. Backing up of water from downstream ice jams after breakup may also impact hydrograph shape promoting high peak flow after release and may increase uncertainty associated with discharge measurements (ASCE, 1996). Increasing flows at the confluence of the La Salle River and the Elm River Channel located downstream of 05OG008 may also create backwater conditions where channel capacity is exceeded. According to the WSC field notes, this seems to be the reason for the backwater in 2011, which was caused by the discharge from a controlled breech in the dikes of the Assiniboine River being routed through the Elm River Channel. Overall, backwater conditions seem to be quite frequent in sub-catchment LS-05OG008 according to the present analysis and based on field observations. Due to changes in flow conditions, discharge measurements are recommended on a regular basis after high-flow events or ice breakup; if a shift in the rating curve is necessary to accommodate the new flow conditions, a complete new set of discharge measurements must be made (Coulson, 1991). Thus, the peak flows in the observed records could have been exacerbated due to ice conditions and backwater.

\subsection{Effect of stream discharge uncertainty on model performance}

Model performance may also be reduced during backwater periods. Flow routing was calculated in CRHM using the Muskingum model, which is not accurate for rapidly raising hydrographs routed through flat sloping rivers and neglects backwater effects due to tributary inflows and presence of dams (Fread, 1993). These features are characteristic of the study area and may have influenced the model simulations. Alternative distributed flow models such as the kinematic wave model and the Muskingum-Cunge model are also impacted by the backwater effect, which limits the selection of alternative methods for flood routing. Dynamic routing models that solve the Saint-Venant equations are not limited by backwater conditions; however, no analytical solution of the complete set of equations is available for most practical applications (Fread, 1993). Thus, numerical solutions based on finite-element or finite-difference schemes are usually required. Computational inefficiency, numerical instability, and convergence are among the drawbacks of such solutions, which explain the adoption of simpler routing methods in many hydrological models. This remains a major chal-
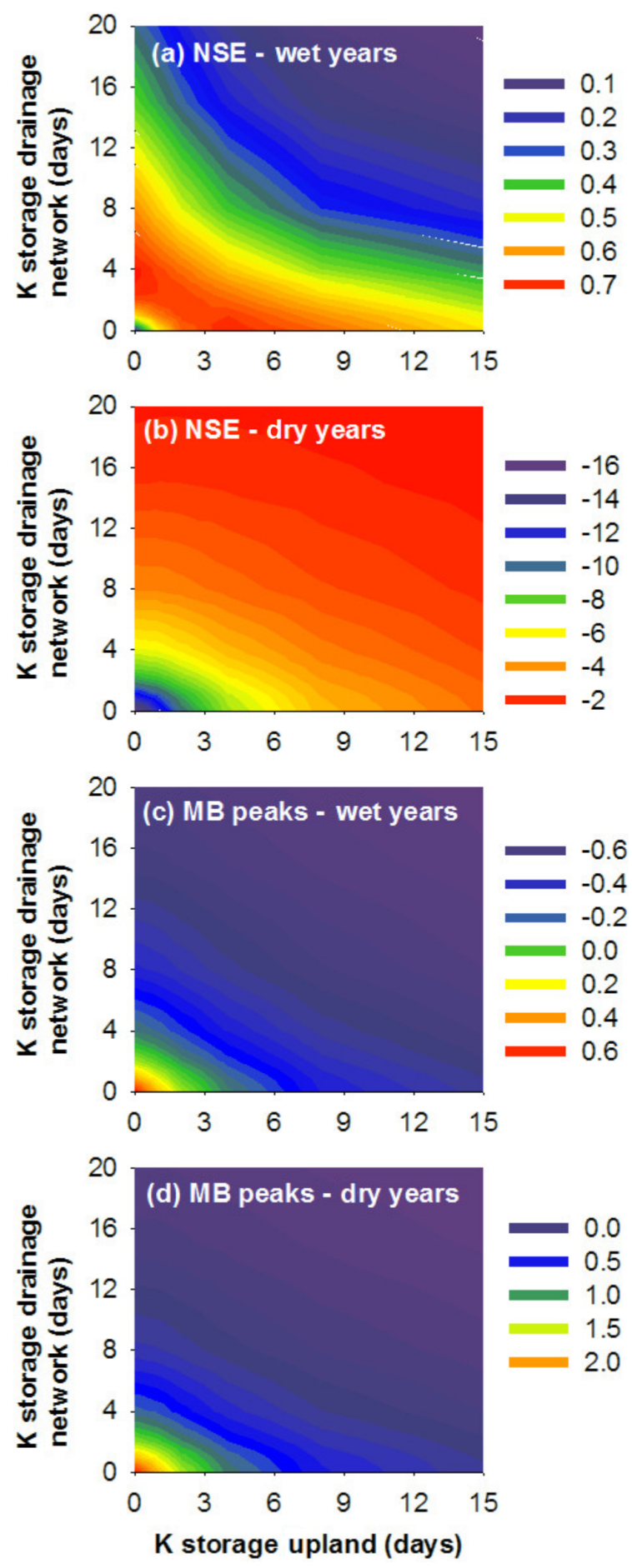

Figure 9. Sensitivity analysis of the K storage parameter in the Muskingum model for the upland areas and drainage network using the Nash-Sutcliffe efficiency (NSE) and peak-flow model bias (MB) as objective functions.

lenge for the application of most hydrological models to catchments such as the La Salle River watershed. 
Table 6. Selected statistical metrics (i.e. NSE and model bias) for falsified models.

\begin{tabular}{lrr|rr|rr|rr}
\hline \multirow{2}{*}{ Year } & \multicolumn{2}{c|}{$\begin{array}{c}\text { Snow } \\
\text { sublimation }\end{array}$} & \multicolumn{2}{c|}{$\begin{array}{c}\text { Blowing } \\
\text { snow }\end{array}$} & \multicolumn{2}{c|}{$\begin{array}{c}\text { Frozen-soil } \\
\text { infiltration }\end{array}$} & \multicolumn{2}{c}{$\begin{array}{c}\text { Frozen-soil infiltration } \\
\text { and blowing snow }\end{array}$} \\
\cline { 2 - 8 } & NSE & MB & NSE & MB & NSE & MB & NSE & MB \\
\hline 1992 & -0.43 & 0.17 & -0.62 & 0.10 & -0.21 & -10.80 & -0.15 & -0.10 \\
1993 & -0.80 & 0.47 & -0.59 & 0.40 & -0.02 & 13.60 & 0.02 & 0.09 \\
1994 & -29.18 & 2.09 & -28.89 & 1.91 & -11.43 & 216.00 & -11.54 & 2.22 \\
1995 & -0.23 & 0.77 & -0.59 & 0.79 & 0.31 & 26.30 & 0.34 & 0.23 \\
1996 & 0.48 & 0.64 & 0.12 & 0.59 & 0.22 & -6.90 & 0.22 & -0.21 \\
2002 & -39.64 & 2.80 & -41.84 & 2.46 & -1.37 & 85.00 & -0.73 & 0.67 \\
2003 & -1.52 & 0.30 & -1.74 & 0.13 & -0.14 & 9.80 & -0.01 & 0.05 \\
2005 & 0.89 & 0.03 & 0.90 & -0.08 & -0.05 & -40.90 & -0.05 & -0.50 \\
2006 & 0.83 & -0.29 & 0.81 & -0.35 & -0.18 & -77.20 & -0.19 & -0.81 \\
2007 & -0.86 & 1.13 & -0.88 & 0.96 & -0.10 & -30.10 & 0.00 & -0.44 \\
2009 & 0.68 & -0.16 & 0.66 & -0.16 & -0.07 & -64.50 & 0.02 & -0.63 \\
2010 & 0.35 & -0.26 & 0.33 & -0.30 & 0.30 & -28.80 & 0.31 & -0.31 \\
2011 & 0.89 & -0.23 & 0.86 & -0.24 & 0.10 & -47.30 & 0.10 & -0.53 \\
2012 & -1.16 & 0.38 & -0.64 & 0.26 & -0.14 & 63.40 & -0.29 & 0.68 \\
2013 & 0.67 & 0.39 & 0.09 & 0.44 & 0.01 & -12.00 & 0.05 & -0.19 \\
Average & -4.60 & 0.55 & -4.80 & 0.46 & -0.85 & 6.37 & -0.79 & 0.02 \\
\hline
\end{tabular}

Ice covered and backwater conditions create added uncertainty during assessment of model performance, making evaluation for LS-05OG008 more challenging, but this problem is likely to be characteristic of other rivers in the Red River Valley given the relatively flat topography, the presence of water level control structures/dams along the river channels, the presence of ice during peak flows, and frequent backwater at the confluence of rivers and streams. It has been suggested that input errors in precipitation datasets are the dominant source of error in hydrological modelling, while errors in streamflow data are much smaller (Kavetski et al., 2006). While this premise is generally accepted, the results shown in the present study suggest that uncertainty regarding streamflow records in agricultural cold regions can be particularly complex.

Despite the uncertainty associated with representation of in-stream dynamics during ice and backwater conditions, CRHM was able to capture the overall trend in streamflow with satisfactory simulation of the timing and magnitude of wet years (when peak flows were above the median). However, even in those years, the peak flows were underestimated by the model.

\subsection{Sensitivity analysis of the storage parameter in the Muskingum model}

Model performance could also have been affected by different routing conditions taking place during dry and wet years. The contour plots of the NSE and peak-flow MB for both wet and dry years suggest that constant $\mathrm{K}$ storage values are not adequate for representing both hydrological regimes and that dynamical storage might be present in the basin (Fig. 9).
Constant values of the Muskingum parameters make them dependent on the hydrological flow data used to derive them, while it has been suggested that a more physically realistic approach is to allow the parameters to vary in time and space according to flow variability (Guang-Te and Singh, 1992). Due to this limitation, methodologies have been devised for application of the Muskingum model with variable parameters (Guang-Te and Singh, 1992; Song et al., 2011). In the present study, the K storage parameter was adequate for representing wet conditions only, since good model performance was achieved by the model for those conditions. However, $\mathrm{K}$ storage alone was not enough to explain the poor performance during dry years since the NSE was consistently negative even for large $\mathrm{K}$ storage values. Trends towards large $\mathrm{K}$ storage (i.e. slow movement of overland runoff and channel routing) and overestimation of discharge for dry years (Figs. 3 and 5) suggest that other physical processes such as dynamical macropores affecting infiltration through soil cracks could be underestimated during simulations that were designed to address wet condition flowpaths. In-channel processes such as water pooling and natural damming may also explain the large $\mathrm{K}$ storage values for drier years.

\subsection{Model performance in wet years}

This application of the CHRM has a very high proportion of the watershed used as cropland (87\%), extremely level topography, and modest depressional storage, which is unique and contrasts with other agricultural applications of the CRHM in land use proportions and topographic relief (Mahmood et al., 2017; Fang et al., 2010; Pomeroy et al., 2007, 2014). The land use split method, used in other 

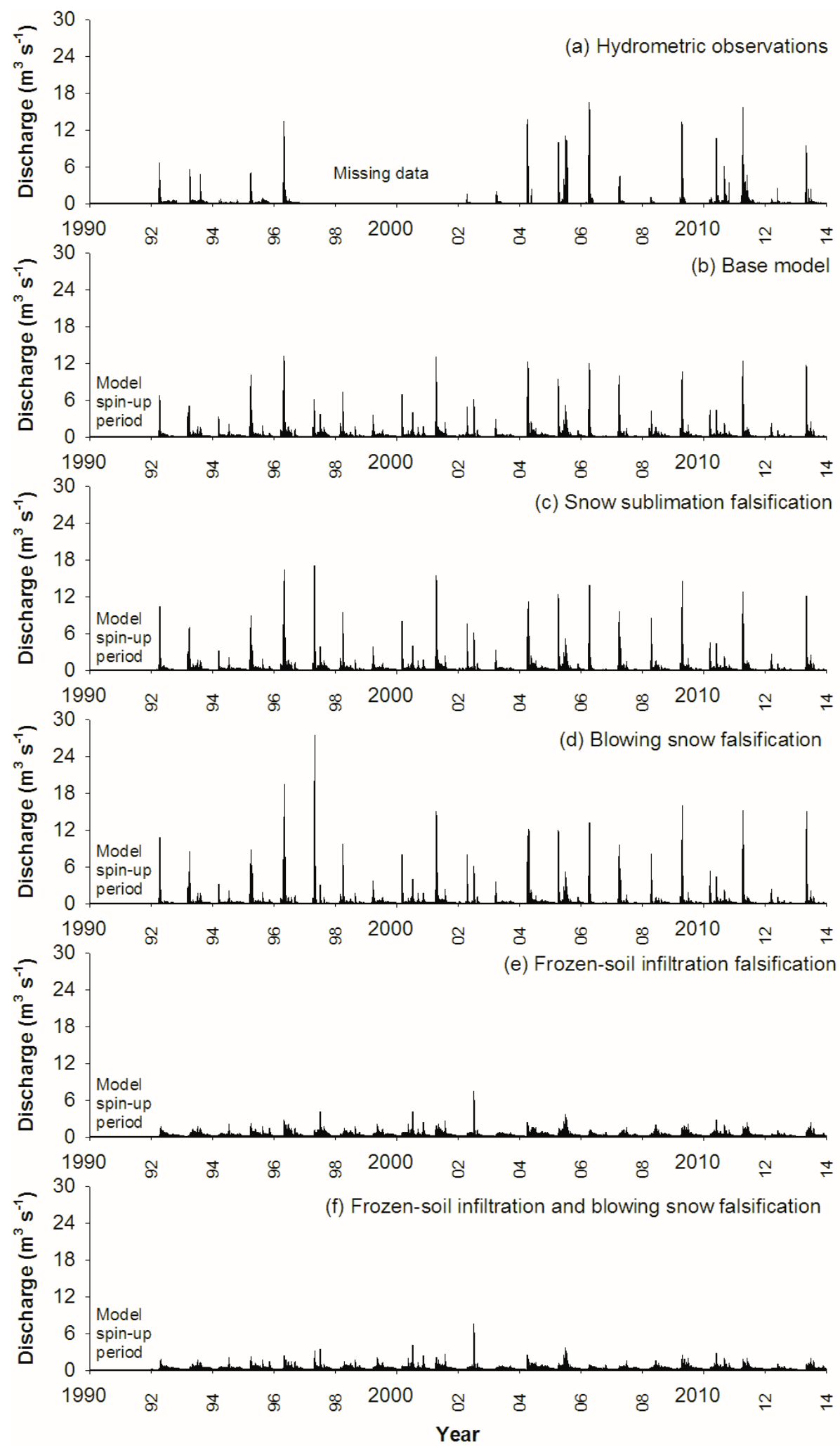

Figure 10. Observed hydrograph (a) and model simulations (1992-2013) for the base model (b) and the different model falsifications, which include inhibition of snow sublimation (c), blowing snow (d), frozen-soil infiltration (e) and frozen-soil infiltration combined with blowing snow (f). Model spin-up period shown for reference only. 
modelling efforts in this watershed (Yang et al., 2014) to represent crop rotations in a static fashion in a multi-year model exercise, seemed to work well for the application in this study given the good simulations in wet years. Simulations of SWE, evaporation, and VWC were validated by external datasets, indicating that the model state variables were in good agreement with the major hydrological processes in the agricultural landscape. Small yearly differences in evaporation were likely due to differences in input data, location, and method, where AAFC applies Meyer's revised formula (Martin, 2002) for lakes and the CRHM uses the PriestleyTaylor procedure for wetlands and small lakes. Differences in soil moisture values could be due to differences in soil properties used to calculate the water holding capacity of the soil. Good simulation of model state variables increases the confidence in the runoff simulations and highlights the value of the physically based approach used by the CRHM to represent agricultural landscapes. Proper simulation of these variables reinforces the fact that the physical description of the relevant hydrological processes is accurate for cold regions, underpinning the use of models that do not require calibration, such as the one developed in the present study for use in cold-climate agricultural areas. Proper simulation of state variables also enables the model to assess other scenarios not simulated here. For example, changes in land use could be simulated by altering model parameters.

\subsection{Model performance in dry years}

The model did not show satisfactory performance in dry years. Poor model performance in dry years is not completely unexpected since low flows are generally more difficult to predict than larger flows (Nicolle et al., 2014), particularly for small catchment areas (Stanfield et al., 2009). This difficulty may also have been aggravated if there was flow under or over ice. The general pattern of flow is represented during drier years and overestimation appears not to be caused by overestimation of baseflow; rather, problems are most evident as overestimation of peak flows (e.g. years 1994 and 2002 in Fig. 3). While drought conditions and in-stream flow requirements are important considerations on the Prairies from a land use and water management perspective (Fang and Pomeroy, 2007), the smaller magnitude events account for very little of the overall export of water and phosphorus from the La Salle River (Corriveau et al., 2013), and the CRHM appears to be a promising tool for physically based simulation of the impact of management change on watershed hydrology in intensively agricultural tributaries of the Red River where elevated nutrient export is of particular concern.

Emulation of preferential flow by allowing infiltration prior to the major melt event resulted in improved simulations more than $30 \%$ of the time in dry years, which suggests that this mechanism is a hydrological control influencing stream discharge under dry conditions. While the method chosen does not capture all the complex nuances of preferential flow, it does allow for enhanced infiltration and mimics the same effects of this mechanism. Interestingly, the 2 years that resulted in improved simulations (i.e. 2002 and 2012) were dry years preceded by years with wet springs and dry summers. In 2001, well-above-normal precipitation in the spring was followed by a dry summer and fall (Wheaton et al., 2008). The same was observed in 2011 (Cordeiro et al., 2014). This similar trend highlights the importance of antecedent conditions for preferential flow. In contrast, there was no improvement in dry years followed by dry years (i.e. 1995 and 2003). It is likely that the simulation of infiltration prior to melt was insufficient to account for the magnitude of preferential flow upon prolonged desiccation of the cracking soils in the study area. Granger et al. (1984) showed that dry cracking clays created conditions of "unlimited" infiltration into frozen soils - such high infiltration rates would provide model outputs more similar to streamflow observations. Regardless, the physically based nature of the simulations suggests that preferential flow deserves investigation as one of the major hydrological controls driving stream discharge in dry years.

Preferential flow through soil cracking is inherently linked to soil moisture content, which itself can also affect streamflow in dry years. A sensitivity analysis of prairie snowmelt to drought in the Creighton catchment in Saskatchewan using the CRHM indicated that large reductions in stream discharge could be driven by reduced winter precipitation, increased winter air temperature, and decreased soil moisture content in the fall (Fang and Pomeroy, 2007). While the area of the Creighton catchment corresponds to less than $10 \%$ (i.e. $11.4 \mathrm{~km}^{2}$ ) of that of the study area in the present study (i.e. $189 \mathrm{~km}^{2}$ ), it had soils in the low-permeability range (i.e. silt clay and clay loams) and $85 \%$ of the land use under cultivated land (stubble or fallow fields), which makes it similar to the characteristics of the La Salle watershed. Simulations of soil moisture (Fig. 8) showed a trend to overestimation in dry years (e.g. 1995, 2003, and 2012), which again highlights the importance of antecedent conditions to stream discharge generation and the need to improve the model representation during droughts. In fact, investigations in the Canadian Prairies, although in an internally drained basin, indicated that snowmelt infiltration is very sensitive to soil moisture in the fall and that hydrologic droughts emerged from low soil moisture conditions (Fang and Pomeroy, 2008). Together these studies indicate the need for further research and improved representation of those processes controlling infiltration and routing of runoff in cold regions with dry antecedent conditions.

\subsection{Model falsifications}

The analysis of model falsification indicates that snow sublimation and blowing snow, as well as infiltration to frozen soils, are crucial for accurate simulations of stream discharge 
in the flat, intensively managed agricultural watershed of the La Salle River. The prominence of snow sublimation effects over snow transport contrasts with results observed for mountain environments where greater importance of snow transport has been identified (Zhou et al., 2014). However, snow transport and redistribution within this watershed was still of importance, despite no loss of snow from the watershed. Inclusion of snow transport affected peak and total discharge, with a more pronounced effect on the latter (Table 5). Inhibition of blowing snow sublimation caused a reduction in total discharge in 2 out of 21 years $(9 \%$ of the time) when compared to the base model, while inhibition of both blowing snow sublimation and transport caused a reduction of this variable in 8 out of 21 years $(38 \%$ of the time). Accumulation of snow within watersheds tends to occur in association with steep hills and valley slopes (Pomeroy and Goodison, 1997). In the lower slope landscape of the La Salle watershed, snow accumulates in deep drainage ditches and stream channels. If snow transport is inhibited, the stimulated accumulation of snow in these topographic features decreases and greater snowmelt is simulated for upland areas. This increases potential for infiltration, which could explain the reduction in total discharge associated with inhibition of snow transport. This pattern stresses the importance of internal snow redistribution within the watershed to stream discharge generation despite snow transport not impacting peak discharge to the same extent as blowing snow sublimation. The pattern also provides some insight into the potential for wind barrier sites such as shelterbelts to retain snow in upland areas (Steyn et al., 1997) to encourage infiltration and reduce runoff generation with melt.

Regarding infiltration into frozen soils, falsifying this process had an overriding effect over falsification of blowing snow since peak discharge was consistently reduced in these models, despite the trend of increased peak and total discharge arising from falsification of snow processes (Table 5). These results emphasize the importance of infiltration to stream discharge generation. This process has been indirectly discussed by Gray et al. (1986) and van der Kamp et al. (2003), who observed reduced runoff for land uses with enhanced infiltration. Since runoff is the primary source of stream discharge in the Canadian Prairies (Shook and Pomeroy, 2012, 2010), the importance of frozen soil infiltration could be more pronounced than that of the blowing snow process to streamflow generation. The model falsification indicates that peak discharges would be reduced, on average, by $61 \%$ where infiltration into frozen soil is modelled at non-frozen rates, while inhibition of snow processes would increase peak discharges by $39 \%$ on average.

\section{Summary and conclusions}

Simulation of streamflow in an intensively managed agricultural tributary of the Red River (the La Salle River) with the CRHM platform revealed a number of topics for which knowledge of hydrological processes in the region and model representation might be improved. (1) Ice and backwater issues are likely to contribute to increased uncertainty in both measured hydrometric data and model representations for tributaries of the Red River. Among the drivers of these issues are the low relief of topography of the region, the presence of water level control structures/dams along the river channel, the presence of ice during peak flows, and frequent confluences of streams and artificial channels. Future modelling efforts in the region should focus on estimating the model uncertainty arising from ice and dam effects on hydrometric data. (2) Simulation of low-flow years remains challenging in the La Salle River, as is commonly reported for other hydrological models. In low-flow years, discharge was overestimated by $90 \%$ and a sensitivity analysis of the storage parameter of the Muskingum routing model indicated that averaging this parameter is not adequate for the study area. Also, improved simulations in dry years through emulation of preferential flow by allowing infiltration prior to the major melt event suggest that even where frozen soil predominates, preferential flow may be an important hydrological feature under dry conditions for the high clay content soils of the Red River Valley. As such, dynamic representation of processes such as infiltration through macropores may require revision for drier conditions in the Red River Valley. Research efforts using modelling frameworks should try to implement simulation of preferential flow pathways, especially under dry conditions.

Despite the potential to improve model representation identified through this research, it is also evident that performance metrics for the CRHM platform indicate very good simulation of peak and annual cumulative flows in the La Salle River where flows were equal to or above median values (under normal to wet conditions). On average, annual discharge was underestimated by only $5 \%$ in wet years. The good performance of the model in average or above-average flow years indicates that CRHM simulations are likely appropriate for use in regional nutrient-transport assessments where export is largely determined by hydrological drivers in the study area and for assessment of land use and climate change impacts on streamflow.

Falsifications of blowing snow transport and sublimation, and infiltration to frozen soil processes in the validated base model indicate that these processes were very influential in stream discharge generation. Inhibition of snow sublimation would represent an average increase in peak discharge of around $25 \%$, while inhibition of blowing snow, which includes both snow sublimation and transport, would cause an increase in peak discharge of around $39 \%$. Simulation of infiltration without changes to model structure to account for frozen soils would cause a reduction in peak discharge of around $61 \%$. 
Code and data availability. CRHM codes are available through model developers. Details can be found at http://www.usask.ca/hydrology/CRHM.php.

The weather and hydrometric datasets used in this research are publicly accessible through the Government of Canada's Open Data portal (http://open.canada.ca) and Environment and Climate Change Canada websites:

weather data: Environment and Climate Change Canada (2015a);

Hydrometric data: Environment and Climate Change

Canada (2015b).

Details about the hydrological and meteorological datasets are provided by Cordeiro et al. (2017, https://doi.org/10.5194/essd2017-57).

\section{The Supplement related to this article is available online at https://doi.org/10.5194/hess-21-3483-2017- supplement.}

Team list. Sampsa Hamalainen (land use analyst; Science and Technology Branch, Agriculture and Agri-Food Canada); Patsy Michiels (land resource analyst; Science and Technology Branch, Agriculture and Agri-Food Canada); Kurt Gottfried (GIS specialist; Science and Technology Branch, Agriculture and Agri-Food Canada); Zhiqiang Yu (Post-doctoral Fellow; Science and Technology Branch, Agriculture and Agri-Food Canada).

Author contributions. MRCC, HFW, and JV conceived the modelling objectives, scope, and strategy; MRCC and JV acquired the input data; MRCC, JPP, and XF developed the custom model for analysis; MRCC and HFW performed data analysis; MRCC prepared the manuscript with contributions from all co-authors.

Competing interests. The authors declare that they have no conflict of interest.

Acknowledgements. This research was supported by funding under Agriculture and Agri-Food Canada's Growing Forward 2 program. The authors are grateful for the input provided by Jarrett Powers and the soil moisture data provided by Catherine Champagne from Agriculture and Agri-Food Canada. Collaboration in the preparation of model input data with Zhiqiang Yu and our discussions about characteristics of the watershed are greatly appreciated.

Edited by: Fuqiang Tian

Reviewed by: two anonymous referees

\section{References}

ASCE: Hydrology Handbook, 2nd Edn., ASCE, 1996.

Benoy, G. A., Jenkinson, R. W., Robertson, D. M., and Saad, D. A.: Nutrient delivery to Lake Winnipeg from the RedAssiniboine River Basin - A binational application of the
SPARROW model, Can. Water Resour. J., 41, 429-447, https://doi.org/10.1080/07011784.2016.1178601, 2016.

Beven, K. J.: Rainfall-Runoff Modelling: The Primer, Wiley, West Sussex, UK, 2011.

Blanke, A., Rozelle, S., Lohmar, B., Wang, J., and Huang, J.: Water saving technology and saving water in China, Agricult. Water Manage., 87, 139-150, https://doi.org/10.1016/j.agwat.2006.06.025, 2007.

Brooks, R. H. and Corey, A. T.: Properties of porous media affecting fluid flow, J. Irr. Drain. Div.-ASCE, 92, 61-88, 1966.

Brunet, N. N. and Westbrook, C. J.: Wetland drainage in the Canadian prairies: Nutrient, salt and bacteria characteristics, Agr. Ecosyst. Environ., 146, 1-12, https://doi.org/10.1016/j.agee.2011.09.010, 2012.

Buttle, J.: Mapping first-order controls on streamflow from drainage basins: the T3 template, Hydrol. Proc., 20, 3415-3422, https://doi.org/10.1002/hyp.6519, 2006.

Carter, R. W. and Godfrey, R. G.: Storage and flood routing, USGS, Washington, DC, 1960

Cherkauer, K. A., Bowling, L. C., and Lettenmaier, D. P.: Variable infiltration capacity cold land process model updates, Global Planet. Change, 38, 151-159, https://doi.org/10.1016/S09218181(03)00025-0, 2003.

Chipanshi, A. C., Warren, R. T., L'Heureux, J., Waldner, D., McLean, H., and Qi, D.: Use of the National Drought Model (NDM) in Monitoring Selected Agroclimatic Risks Across the Agricultural Landscape of Canada, Atmos. Ocean, 51, 471-488, https://doi.org/10.1080/07055900.2013.835253, 2013.

Cordeiro, M. R. C., Sri Ranjan, R., Ferguson, I. J., and Cicek, N.: Nitrate, phosphorus, and salt export through subsurface drainage from corn fields in the Canadian Prairies, T. Am. Soc. Agricult Eng., 57, 43-50, https://doi.org/10.13031/trans.57.10370, 2014.

Cordeiro, M. R. C., Vanrobaeys, J. A., and Wilson, H. F.: Long-term weather, hydrometric, and water chemistry datasets in high-temporal resolution at the La Salle River watershed in Manitoba, Canada, Earth Syst. Sci. Data Discuss., https://doi.org/10.5194/essd-2017-57, in review, 2017.

Corey, A. T.: Mechanics of Immiscible Fluids in Porous Media, Water Resources Publications, 1994.

Corriveau, J., Chambers, P., and Culp, J.: Seasonal Variation in Nutrient Export Along Streams in the Northern Great Plains, Water Air Soil Pollut., 224, 1-16, https://doi.org/10.1007/s11270-0131594-1, 2013.

Coulson, C. H.: Manual of Operational Hydrology in British Columbia, Ministry of Environment, Water Management Division, Hydrology Section, Victoria, BC, 234 pp., 1991.

Desaulniers, K. L. and Gritzner, C. F.: Northern America, Facts On File, Incorporated, 2006.

Dornes, P. F., Tolson, B. A., Davison, B., Pietroniro, A., Pomeroy, J. W., and Marsh, P.: Regionalisation of land surface hydrological model parameters in subarctic and arctic environments, Phys. Chem. Earth, 33, 1081-1089, https://doi.org/10.1016/j.pce.2008.07.007, 2008.

Douglas-Mankin, K. R., Srinivasan, R., and Arnold, J. G.: Soil and Water Assessment Tool (SWAT) Model: Current Developments and Applications, T. ASABE, 53, 1423-1431, https://doi.org/10.13031/2013.34915, 2010.

Ehrlich, W. A., Poyser, E. A., Pratt, L. E., and Ellis, J. H.: Report of Reconnaissance Soil Survey of Winnipeg and Morris Map Sheet 
Areas, Manitoba Department of Agriculture, Winnipeg, MBSoils Report No. 5, 1953.

Ellis, C. R., Pomeroy, J. W., Brown, T., and MacDonald, J.: Simulation of snow accumulation and melt in needleleaf forest environments, Hydrol. Earth Syst. Sci., 14, 925-940, https://doi.org/10.5194/hess-14-925-2010, 2010.

Environment and Climate Change Canada: Weather Data, Historical Climate Data, available at: http://climate.weather.gc.ca/ (last access: 22 February 2016), 2015a.

Environment and Climate Change Canada: Hydrometric data, HYDAT Database-National Water Data Archive, available at: https:// ec.gc.ca/rhc-wsc/default.asp?lang=En\&n=9018B5EC-1 (last access: 22 February 2016), 2015b.

Fang, X. and Pomeroy, J. W.: Snowmelt runoff sensitivity analysis to drought on the Canadian prairies, Hydrol. Proc., 21, 25942609, https://doi.org/10.1002/hyp.6796, 2007.

Fang, X. and Pomeroy, J. W.: Drought impacts on Canadian prairie wetland snow hydrology, Hydrol. Proc., 22, 2858-2873, https://doi.org/10.1002/hyp.7074, 2008.

Fang, X., Pomeroy, J. W., Westbrook, C. J., Guo, X., Minke, A. G., and Brown, T.: Prediction of snowmelt derived streamflow in a wetland dominated prairie basin, Hydrol. Earth Syst. Sci., 14, 991-1006, https://doi.org/10.5194/hess-14-991-2010, 2010.

Fang, X., Pomeroy, J. W., Ellis, C. R., MacDonald, M. K., DeBeer, C. M., and Brown, T.: Multi-variable evaluation of hydrological model predictions for a headwater basin in the Canadian Rocky Mountains, Hydrol. Earth Syst. Sci., 17, 1635-1659, https://doi.org/10.5194/hess-17-1635-2013, 2013.

Fread, D.: Flow Routing, in: Handbook of Hydrology, edited by: Maidment, D. R., McGraw-Hill, New York, 10.11-10.36, 1993.

Granger, R., Gray, D., and Dyck, G.: Snowmelt infiltration to frozen prairie soils, Can. J. Earth Sci., 21, 669-677, https://doi.org/10.1016/0148-9062(85)92399-X, 1984.

Graveline, P. G. and Larter, J.: La Salle Redboine Conservation District: La Salle River watershed assessment survey - with emphasis on La Salle River, Elm River, Elm Creek channel, and The King drain - 2005, Winnipeg, MB, 107, 2006.

Gray, D. and Prowse, T.: Snow and Floating Ice, in: Handbook of Hydrology, edited by: Maidment, D. R., McGraw-Hill, New York, 7.1-7.58, 1993.

Gray, D., Pomeroy, J., and Granger, R.: Prairie snowmelt runoff, Water research themes, Conference commemorating the official opening of the National Hydrology Research Centre, 49-68, 1986.

Grizzetti, B., Bouraoui, F., Granlund, K., Rekolainen, S., and Bidoglio, G.: Modelling diffuse emission and retention of nutrients in the Vantaanjoki watershed (Finland) using the SWAT model, Ecol. Model., 169, 25-38, https://doi.org/10.1016/S03043800(03)00198-4, 2003

Guang-Te, W. and Singh, V. P.: Muskingum method with variable parameters for flood routing in channels, J. Hydrol., 134, 57-76, https://doi.org/10.1016/0022-1694(92)90028-T, 1992.

Harder, P. and Pomeroy, J. W.: Hydrological model uncertainty due to precipitation-phase partitioning methods, Hydrol. Proc., 28, 4311-4327, https://doi.org/10.1002/hyp.10214, 2014.

Kavetski, D., Kuczera, G., and Franks, S. W.: Bayesian analysis of input uncertainty in hydrological modeling: 1. Theory, Water Resour. Res., 42, W03407, https://doi.org/10.1029/2005WR004368, 2006.
Kim, S.-B., Huang, H.-T., Tsang, L., Jackson, T., McNairn, H., and Zyl, J. V.: Soil moisture retrieval using L-band time-series SAR data from the SMAPVEX12 experiment, Proceedings of EUSAR 2014; 10th European Conference on Synthetic Aperture Radar, $1-4,2014$.

King, K. W., Williams, M. R., Macrae, M. L., Fausey, N. R., Frankenberger, J., Smith, D. R., Kleinman, P. J. A., and Brown, L. C.: Phosphorus transport in agricultural subsurface drainage: A review, J. Environ. Qual., 44, 467-485, https://doi.org/10.2134/jeq2014.04.0163, 2015.

Knisel, W. G. and Turtola, E.: Gleams model application on a heavy clay soil in Finland, Agr. Water Manage., 43, 285-309, https://doi.org/10.1016/S0378-3774(99)00067-0, 2000.

Kossieris, P., Tyralis, H., Koutsoyiannis, D., and Efstratiadis, A.: HyetosR: A package for temporal stochastic simulation of rainfall at fine time scales, $\mathrm{R}$ package version $0.0-2$, http://www.itia. ntua.gr/, 2013.

Koutsoyiannis, D. and Onof, C.: Rainfall disaggregation using adjusting procedures on a Poisson cluster model, J. Hydrol., 246, 109-122, https://doi.org/10.1016/S0022-1694(01)00363-8, 2001.

Krogh, S. A., Pomeroy, J. W., and McPhee, J.: Physically based mountain hydrological modeling using reanalysis data in Patagonia, J. Hydrometeorol., 16, 172-193, https://doi.org/10.1175/jhm-d-13-0178.1, 2015.

La Salle Redboine Conservation District: La Salle River Watershed - State of the Watershed Report, Holland, Manitoba, 296, 2007.

Li, H., Sivapalan, M., Tian, F., and Liu, D.: Water and nutrient balances in a large tile-drained agricultural catchment: a distributed modeling study, Hydrol. Earth Syst. Sci., 14, 2259-2275, https://doi.org/10.5194/hess-14-2259-2010, 2010.

Liu, S., Mo, X., Liu, C., Xia, J., and Zhao, W.: How to maximize the predictive value of available data in ungauged basins? - Chinese lesson, in: Putting Prediction in Ungauged Basins into Practice, edited by: Pomeroy, J. W. and Whitfield, P. H., Canadian Water Resources Association, 2013.

Liu, Y. B., Yang, W. H., Gharabaghi, B., Liu, J. Z., Wu, H., and Yarotski, J.: Characterizing snow redistribution in SWAT for simulating spatially distributed snowmelt runoff in cold regions, Nonlin. Sci. Lett. C, 2, 1-8, 2012.

Mahmood, T. H., Pomeroy, J. W., Wheater, H. S., and Baulch, H. M.: Hydrological responses to climatic variability in a cold agricultural region, Hydrol. Proc., 31, 854-870, https://doi.org/10.1002/hyp.11064, 2017.

Martin, F. R. J.: Gross Evaporation for the 30 Year Period 1971-2000 in the Canadian Prairies, Agriculture and Agri-Food Canada, Prairie Farm Rehabilitation Administration, Technical Service, Regina, SK, 2002.

McCullough, G. K., Page, S. J., Hesslein, R. H., Stainton, M. P., Kling, H. J., Salki, A. G., and Barber, D. G.: Hydrological forcing of a recent trophic surge in Lake Winnipeg, J. Great Lakes Res., 38, 95-105, https://doi.org/10.1016/j.jglr.2011.12.012, 2012.

Michalyna, W., Smith, R. E., and Milne, R. A.: Soils of the Portage La Prairie Area, Manitoba Department of Agriculture, Winnipeg, MBSoil Report No. 17, 1972.

Mosley, M. P. and McKerchar, A. I.: Streamflow, in: Handbook of Hydrology, edited by: Maidment, D. R., McGraw-Hill, New York, 8.1-8.35, 1993. 
Mou, L., Tian, F., Hu, H., and Sivapalan, M.: Extension of the Representative Elementary Watershed approach for cold regions: constitutive relationships and an application, Hydrol. Earth Syst. Sci., 12, 565-585, https://doi.org/10.5194/hess-12565-2008, 2008.

Nicolle, P., Pushpalatha, R., Perrin, C., François, D., Thiéry, D., Mathevet, T., Le Lay, M., Besson, F., Soubeyroux, J.-M., Viel, C., Regimbeau, F., Andréassian, V., Maugis, P., Augeard, B., and Morice, E.: Benchmarking hydrological models for low-flow simulation and forecasting on French catchments, Hydrol. Earth Syst. Sci., 18, 2829-2857, https://doi.org/10.5194/hess-18-28292014, 2014.

OECD: Canada case study, in: Providing Agri-environmental Public Goods through Collective Action, OECD Publishing, Paris, France, 155-170, 2013.

Parry, M. L., Carter, T. R., and Konijn, N. T.: The Impact of Climatic Variations on Agriculture, Assessment in Cool Temperate and Cold Regions, Springer Science, Vol. 1, 1988.

Paterson, W. S. B.: The Physics of Glaciers, Butterworth/Heinemann, 1994.

Pomeroy, J. W. and Goodison, B. E.: Winter and snow, in: The Surface Climates of Canada, edited by: Bailey, W. G., Oke, T. R., and Rouse, W., MCGill-Queen's University Press, Montreal, 68-100, 1997.

Pomeroy, J. W. and Gray, D. M.: Snowcover accumulation, relocation and management, 2, Environment Canada, 1995.

Pomeroy, J. and Li, L.: Prairie and arctic areal snow cover mass balance using a blowing snow model, J. Geophys. Res., 105, 2661926634, 2000.

Pomeroy, J. W., Gray, D. M., Brown, T., Hedstrom, N. R., Quinton, W. L., Granger, R. J., and Carey, S. K.: The cold regions hydrological model: a platform for basing process representation and model structure on physical evidence, Hydrol. Proc., 21, 26502667, https://doi.org/10.1002/hyp.6787, 2007.

Pomeroy, J. W., Shook, K., Fang, X., Dumanski, S., Westbrook, C., and Brown, T.: Improving and Testing the Prairie Hydrological Model at Smith Creek Research Basin, Report No. 14, Centre for Hydrology, University of Saskatchewan, Saskatoon, 2014.

Rahman, M. M., Lin, Z., Jia, X., Steele, D. D., and DeSutter, T. M.: Impact of subsurface drainage on streamflows in the Red River of the North basin, J. Hydrol., 511, 474-483, https://doi.org/10.1016/j.jhydrol.2014.01.070, 2014.

Rasouli, K., Pomeroy, J. W., Janowicz, J. R., Carey, S. K., and Williams, T. J.: Hydrological sensitivity of a northern mountain basin to climate change, Hydrol. Proc., 28, 4191-4208, https://doi.org/10.1002/hyp.10244, 2014.

Rattan, K. J., Corriveau, J. C., Brua, R. B., Culp, J. M., Yates, A. G., and Chambers, P. A.: Quantifying seasonal variation in total phosphorus and nitrogen from prairie streams in the Red River Basin, Manitoba Canada, Sci. Total Environ., 575, 649659, https://doi.org/10.1016/j.scitotenv.2016.09.073, 2016.

Roste, J.: Development and Evaluation of a Canadian Prairie Nutrient Transport Model, MSc Thesis, Department of Geography and Planning, University of Saskatchewan, Saskatoon, SK, 2015.

Schierhorn, F., Faramarzi, M., Prishchepov, A. V., Koch, F. J., and Müller, D.: Quantifying yield gaps in wheat production in Russia, Environ. Res. Lett., 9, 084017, https://doi.org/10.1088/17489326/9/8/084017, 2014a.
Schierhorn, F., Müller, D., Prishchepov, A. V., Faramarzi, M., and Balmann, A.: The potential of Russia to increase its wheat production through cropland expansion and intensification, Glob. Food Secur., 3, 133-141, https://doi.org/10.1016/j.gfs.2014.10.007, 2014b.

Sharp, P. F.: The Northern Great Plains: A Study in Canadian-American Regionalism, J. Am. Hist., 39, 61-76, https://doi.org/10.2307/1902844, 1952.

Shook, K. and Pomeroy, J.: Changes in the hydrological character of rainfall on the Canadian prairies, Hydrol. Proc., 26, 1752-1766, https://doi.org/10.1002/hyp.9383, 2012.

Shook, K. R. and Pomeroy, J. W.: Hydrological effects of the temporal variability of the multiscaling of snowfall on the Canadian prairies, Hydrol. Earth Syst. Sci., 14, 1195-1203, https://doi.org/10.5194/hess-14-1195-2010, 2010.

Song, X.-M., Kong, F.-Z., and Zhu, Z.-X.: Application of Muskingum routing method with variable parameters in ungauged basin, Water Sci. Eng., 4, 1-12, https://doi.org/10.3882/j.issn.1674-2370.2011.01.001, 2011.

Spence, C., Whitfield, P. H., Pomeroy, J. W., Pietroniro, A., Burn, D. H., Peters, D. L., and St-Hilaire, A.: A review of the Prediction in Ungauged Basins (PUB) decade in Canada, Can. Water Resour. J., 38, 253-262, https://doi.org/10.1080/07011784.2013.843867, 2013.

Stanfield, L. W., Kilgour, B., Todd, K., Holysh, S., Piggott, A., and Baker, M.: Estimating Summer Low-Flow in Streams in a Morainal Landscape using Spatial Hydrologic Models, Can. Water Resour. J., 34, 269-284, https://doi.org/10.4296/cwrj3403269, 2009.

Steyn, D. G., Schmid, H. P., Walmsley, J. L., and Wilson, J. D.: Spatial variability in surface climates, in: The Surface Climates of Canada, edited by: Bailey, W. G., Oke, T. R., and Rouse, W., MCGill-Queen's University Press, Montreal, 44-67, 1997.

Tian, F., Hu, H., Lei, Z., and Sivapalan, M.: Extension of the Representative Elementary Watershed approach for cold regions via explicit treatment of energy related processes, Hydrol. Earth Syst. Sci., 10, 619-644, https://doi.org/10.5194/hess-10619-2006, 2006.

Tiessen, K. H. D., Elliott, J. A., Yarotski, J., Lobb, D. A., Flaten, D. N., and Glozier, N. E.: Conventional and conservation tillage: influence on seasonal runoff, sediment, and nutrient losses in the Canadian Prairies, J. Environ. Qual., 39, 964-980, https://doi.org/10.2134/jeq2009.0219, 2010.

Ulén, B., Bechmann, M., Fölster, J., Jarvie, H. P., and Tunney, H.: Agriculture as a phosphorus source for eutrophication in the north-west European countries, Norway, Sweden, United Kingdom and Ireland: a review, Soil Use Manage., 23, 5-15, https://doi.org/10.1111/j.1475-2743.2007.00115.x, 2007.

van der Kamp, G., Hayashi, M., and Gallen, D.: Comparing the hydrology of grassed and cultivated catchments in the semi-arid Canadian prairies, Hydrol. Proc., 17, 559-575, https://doi.org/10.1002/hyp.1157, 2003.

Wang, H., Liu, C., and Zhang, L.: Water-saving agriculture in China: An overview, in: Advances in Agronomy, Academic Press, 135-171, 2002.

Watson, B. M., McKeown, R. A., Putz, G., and MacDonald, J. D.: Modification of SWAT for modelling streamflow from forested watersheds on the Canadian Boreal PlainThis article is one of a selection of papers published in this Supplement from the For- 
est Watershed and Riparian Disturbance (FORWARD) Project, J. Environ. Eng. Sci., 7, 145-159, https://doi.org/10.1139/s09-003, 2008.

Weber, M., Bernhardt, M., Pomeroy, J. W., Fang, X., Härer, S., and Schulz, K.: Description of current and future snow processes in a small basin in the Bavarian Alps, Environ. Earth Sci., 75, 1223, https://doi.org/10.1007/s12665-016-6027-1, 2016.

Wheater, H. S. and Gober, P.: Water security and the science agenda, Water Resour. Res., 51, 5406-5424, https://doi.org/10.1002/2015WR016892, 2015.

Wheaton, E., Kulshreshtha, S., Wittrock, V., and Koshida, G.: Dry times: hard lessons from the Canadian drought of 2001 and 2002, Can. Geogr., 52, 241-262, https://doi.org/10.1111/j.15410064.2008.00211.x, 2008.

Wishart, D. J.: Encyclopedia of the Great Plains, University of Nebraska Press, 2004.

Yang, Q., Meng, F.-R., Zhao, Z., Chow, T. L., Benoy, G., Rees, H. W., and Bourque, C. P. A.: Assessing the impacts of flow diversion terraces on stream water and sediment yields at a watershed level using SWAT model, Agr. Ecosyst. Environ., 132, 23-31, https://doi.org/10.1016/j.agee.2009.02.012, 2009.

Yang, Q., Benoy, G. A., Chow, T. L., Daigle, J. L., Bourque, C. P., and Meng, F. R.: Using the soil and water assessment tool to estimate achievable water quality targets through implementation of beneficial management practices in an agricultural watershed, J. Environ. Qual., 41, 64-72, https://doi.org/10.2134/jeq2010.0250, 2012.
Yang, Q., Leon, L. F., Booty, W. G., Wong, I. W., McCrimmon, C., Fong, P., Michiels, P., Vanrobaeys, J., and Benoy, G.: Land use change impacts on water quality in three Lake Winnipeg watersheds, J. Environ. Qual., 43, 1690-1701, https://doi.org/10.2134/jeq2013.06.0234, 2014.

Yates, A. G., Culp, J. M., and Chambers, P. A.: Estimating nutrient production from human activities in subcatchments of the Red River, Manitoba, J. Great Lakes Res., 38, 106-114, https://doi.org/10.1016/j.jglr.2011.04.009, 2012.

Zhang, Z., Kane, D. L., and Hinzman, L. D.: Development and application of a spatially-distributed Arctic hydrological and thermal process model (ARHYTHM), Hydrol. Proc., 14, 1017-1044, https://doi.org/10.1002/(SICI)10991085(20000430)14:6<1017::AID-HYP982>3.0.CO;2-G, 2000.

Zhou, J., Pomeroy, J. W., Zhang, W., Cheng, G., Wang, G., and Chen, C.: Simulating cold regions hydrological processes using a modular model in the west of China, J. Hydrology, 509, 13-24, https://doi.org/10.1016/j.jhydrol.2013.11.013, 2014. 